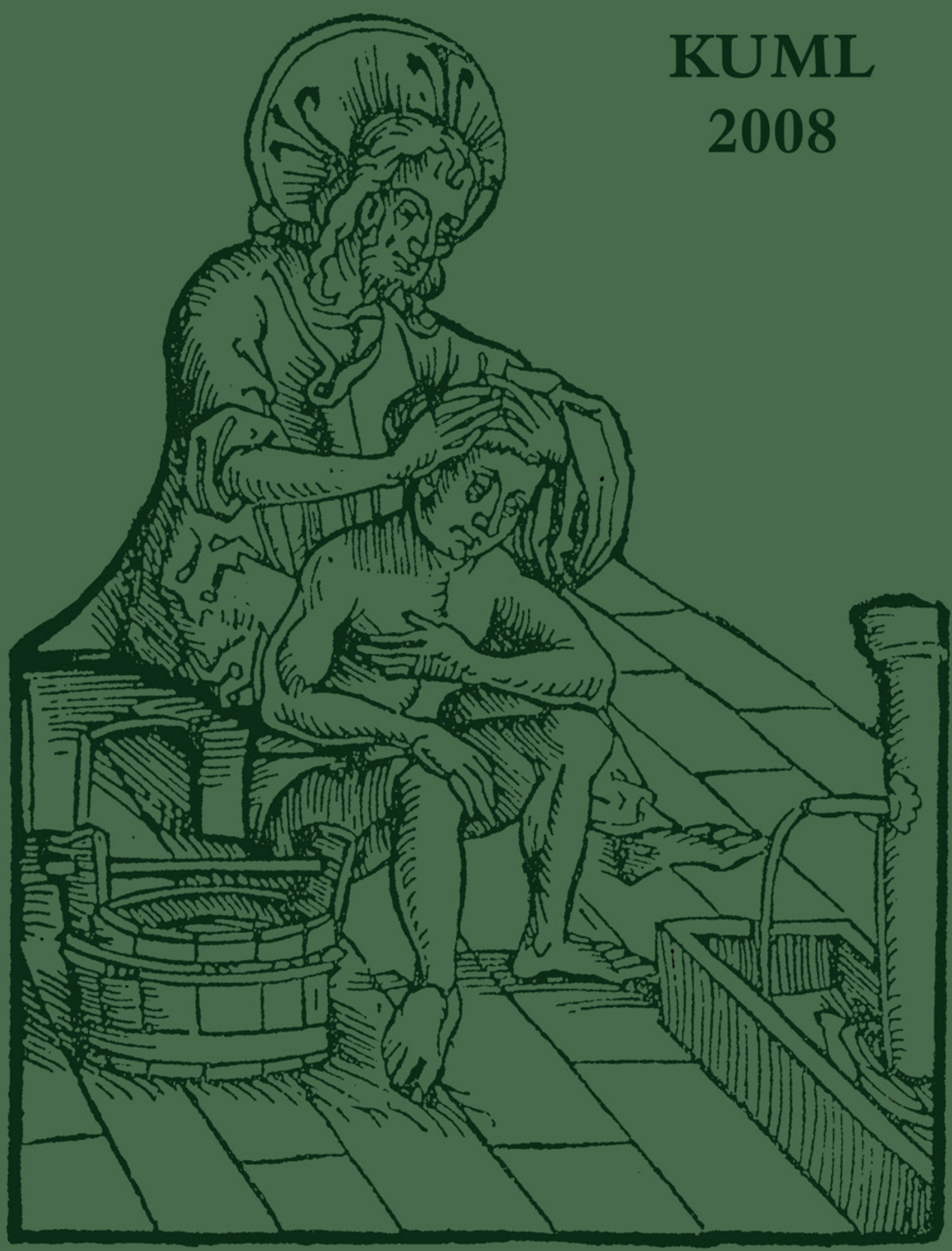




\section{KUML 2008 \\ Årbog for Jysk Arkæologisk Selskab}

With summaries in English

I kommission hos Aarhus Universitetsforlag 


\title{
Badstuer i middelalderen
}

\author{
Af MIKAEL MANØE BJERREGAARD
}

I flere af de danske, middelalderlige købstæder kan man endnu støde på gadenavne som Badstuestræde og Badstuegade. Disse immaterielle levn er i mange tilfælde det sidste spor af de offentlige badstuer, som blomstrede i middelalderens bybillede, men som i tiden efter reformationen hurtigt sygnede hen og helt forsvandt. Badstuevæesnets funktion og status i middelalderens byliv står for nutidens mennesker som et temmelig fremmedartet fænomen, men gennem især skriftlige kilder er det muligt at få et glimt af det liv, som blev levet $\mathrm{i}$ badstuerne i middelalderen, og den plads byens badstue indtog i datidens bevidsthed. Denne artikel omhandler badstuernes kulturhistorie i det middelalderlige Danmark med udgangspunkt i historiske kilder.

\section{Forskningshistorie og anvendt materiale}

I den danske middelalderforskning er der ikke tidligere blevet gjort et forsøg på at skabe et samlet overblik over hvilken viden, der er bevaret om de middelalderlige badstuer i skriftlige kilder og arkæologiske levn. Tidligere er emnet mest indgående behandlet af Troels-Lund i værket »Dagligt liv i Norden i det sekstende århundrede«, der udkom i perioden 1879-1901 - et værk, der ofte henvises til i senere forskning, når badstuer omtales. Troels-Lunds indgangsvinkel til emnet er kulturhistorisk og etnologisk. Med eksempler fra skriftlige kilder og en god del fortælleiver fremmaler han det levede liv i badstuerne og samtidens holdning til badning, og han giver til sidst forklaringsforslag til badstuernes forsvinden i Danmark i løbet af 1500-tallet. Som det fremgår af titlen på hans værk, beskæftiger Troels-Lund sig kun med senmiddelalderens og renæssancens badstuevæsen. Fænomenets rod i tidlig middelalder behandles ikke. En svaghed ved Troels-Lunds gennemgang af badstuevæsnet er, at Norden betragtes som en enhedskultur, og han tager således ikke højde for regionale forskelle. Hans ønske om at formidle et levende og sammenhængende billede af badstuevæsnet på trods af det sparsomme kildemateriale medfører desuden, at der i flere tilfælde er tale om konklusioner baseret på spekulationer snarere end på konkrete kilder. I Sverige udgav Lizzie 
Carlsson i 1947 en artikel, der ud fra en lang række skriftlige kilder grundigt belyser badstuernes udbredelse og brug i det svenske område. I Tyskland udkom i 1906 et stort værk af Alfred Martin, som behandler et stort billedligt og skriftligt materiale fra det tysksprogede område, hvorfra ikke mindst de skriftlige overleveringer er særdeles righoldige. Som noget enestående for det nordeuropæiske område har man i Tyskland også en egentlig bygningsarkæologisk forskning af badstuer, idet man inden for de seneste 20 år er blevet opmærksom på, at der i Sydtyskland og Schweiz stadig er bevaret en række middelalderlige badstuer i stående bygninger. En bygningsarkæologisk tilgang til emnet finder man $i$ artikler af Johannes Cramer samt $i$ en afhandling af Birgit Tuchen fra 2003.

I forbindelse med den nærværende behandling af emnet er alt arkæologisk materiale fra danske museer vedrørende fysiske levn af mulige badstuebygninger blevet gennemgået. Behandlingen af det arkæologiske materiale viste imidlertid, at det fra det middelalderlige danske område på nuværende tidspunkt kun er resterne af en teglstensbygning tæt på Susåen i Næstved, der med stor sandsynlighed kan fastslås at have været en badstue. Når man kan fastslå dette med så stor sikkerhed, skyldes det, at der til bygningen kan hæftes flere eftermiddelalderlige, skriftlige kilder. Sikker viden om middelalderens badstuer skal derfor først og fremmest søges i skriftlige kilder, og den nærværende kulturhistoriske gennemgang vil først og fremmest være baseret på disse. Samtlige kilder i de mest udførlige danske, historiske kildesamlinger for perioden 1100-1536 er således blevet gennemgået for omtaler af badstuer eller relaterede emner. Det drejer sig om Diplomatarium Danicum (perioden 1100-1412), Repertorium diplomaticum (perioden 1413-1512) og Regesta diplomatica historiæ Danicæ (perioden 1513-1536). ${ }^{1}$

\section{Badterminologi}

For at kunne undersøge, hvordan de middelalderlige badstuer blev benyttet, er det nødvendigt først at etablere en entydig terminologi.

På tværs af kulturer og tid findes der overordnet to badtyper: Det våde bad, hvor kroppen nedsænkes i vand, og det tørre bad, hvor kroppen renses gennem svedning, som er fremprovokeret med damp eller varme. Det våde bad kan inddeles i karbade, hvor badet foregår i et kar eller anden form for vandbeholder, samt naturbade i åbent vand som åer, søer eller havet. Da naturbade nødvendigvis foregår udendørs, vil de ikke blive behandlet yderligere i denne artikel. Det tørre bad kan inddeles i tre undertyper, hvor svedning opnås ved hjælp af (1) konstant høj luftfugtighed, (2) tør, hed luft, der med intervaller 
tilføres vanddamp i kortere perioder ved at slå vand på varme sten eller lignende og (3) strålevarme fra en varmekilde helt uden brug af vanddamp.

I faglitteraturen fra både Danmark og de omkringliggende lande anvendes ordene svedebade og dampbade om de tørre bade - ofte uden en klar terminologisk skelnen. Jeg har valgt at undgå ordet dampbad, da dette kan lede til den opfattelse, at baderummet konstant er fyldt med damp, hvilket ifølge den tyske badstueforsker, Birgit Tuchen, ikke har været tilfældet i de europæiske badstuer i middelalderen. ${ }^{2}$ Ordet dampbad forstås her som de islamiske bade (hammam), som er karakteriseret ved en konstant høj luftfugtighed, som opnås via meget varmt, rindende vand og byggematerialer som marmor og fliser, der holder på vanddampene. ${ }^{3}$ Disse badstuer er anderledes konstrueret end de europæiske og falder derfor uden for denne gennemgangs interesseområde. Jeg har valgt at anvende ordet svedebad om den badtype, hvor svedning opnås udelukkende gennem konstant tør varme eller gennem tør varme, der med intervaller tilføres vanddamp. Denne form for svedebad kan måske lettest forstås med det moderne anvendte ord sauna, men jeg vælger at undgå dette begreb, da det er specifikt finsk og derfor kan medføre forvirring og fejlslutninger om badtypens og den dertil knyttede badekulturs oprindelsessted. I en badstue indrettet til svedebad vil man kunne foretage snart et bad med ren strålevarme og snart et bad med korte perioder med vanddampe, uden at det kræver ændringer af badstuens konstruktion.

På moderne islandsk er stadig bevaret to ord med betydningen »bad«: bað og lang. Ordet laug er bevaret på moderne dansk i ordet lørdag, som betyder vaskeeller badedag, og anvendtes i middelalderdansk i ordet for vaske- eller badekar, der betegnedes løvekar. ${ }^{4}$ Tilsyneladende er bað og laug synonymer i den norrøne litteratur, men den norske samfunds- og kulturforsker Eilert Sundt, der i anden del af det 19. århundrede skrev om den norske almues hygiejne, argumenterer for, at ordene oprindelig har betegnet to forskellige badtyper, idet bað er svedebad, og laug er karbad. Af ordet bað er så afledt ordet baðstofa (badstue) som betegnelse for den bygning, hvor svedebade fandt sted. ${ }^{5}$ Sagalitteraturen gør det ikke muligt med sikkerhed at fastslå, om de to ord for »bad« virkelig betegnede to forskellige badtyper, men et eftermiddelalderligt skrift støtter teorien, idet den islandske biskop Dórður Pórláksson i et skrift fra slutningen af 1600-tallet skelner mellem to badtyper, nemlig våde bade (laugar) og tørre bade (baðstofur). ${ }^{6}$ Ifølge »Kulturhistorisk leksikon for nordisk middelalder» omtales dog både kerbad og kerlaug i den norrøne litteratur, så anvendelsen af de to ord har måske ikke været helt entydig. ${ }^{7}$ Konklusionen er, at det i sagalitteraturen fremgår, at begge badtyper blev benyttet, ${ }^{8}$ og det er muligt, at de oprindeligt havde specifikke betegnelser. 


\section{Badning og badstuer i forhistorisk tid og vikingetid}

Der findes ingen førmiddelalderlige, skriftlige kilder, der kan give oplysninger om badtyper eller blot badning i det danske område. Romeren Tacitus skriver i sit værk "Germania « fra omkring år 100 e.Kr., at germanerne vaskede sig om morgenen, oftest i varmt vand. Der tales ikke om egentlige bade. I Rantrum, Kreis Husum i Slesvig-Holsten blev i 1953 udgravet et grubehus fra det første århundrede før Kristus, som er blevet tolket som en badstue til svedebad. 9 Grubehuset var 3×2-2,5 m og havde i det ene hjørne en grube fyldt med varmepåvirkede sten og et askelag. I huset fandtes et stort kar samt en lille skål med hank. Fundene blev tolket som en vandbeholder og en øse til at gyde vand på ovnen med. Muligvis er dette grubehus en tidlig forløber for senere tiders badstuer.

Om vikingernes badevaner beretter en engelsk krønikeskriver, at vikingernes succes med engelske kvinder skyldtes, at de tog bad om lørdagen, redte deres hår og var smukt klædt. ${ }^{10}$ Derimod omtaler araberen Ibn Fadhlan en flok skandinaviske vikinger ved Volga som »de mest beskidte af Allahs skabninger«. Selv om de vasker sig hver morgen, betragtes dette af Ibn Fadhlan også som uhygiejnisk, fordi det foregår i det samme vand. ${ }^{11}$ Også sprogligt findes der spor af skandinavisk badekultur. Som noget enestående for de nordiske sprog har navnet for ugedagen lørdag en oprindelig betydning af vaske- eller badedag. I de islandske sagaer anvendes udtrykket »um baðferðir» om den tid på aftenen, hvor man plejede at bade. ${ }^{12}$ Forekomsten af disse tidsangivelser, der nævner badning, er ikke i sig selv bevis for, at badning faktisk foregik - og slet ikke hver aften eller lørdag - men badning som sådan må have været et vigtigt kulturelt fænomen for at kunne indgå i sproget som tidsangivelse.

Det er muligt, at nogle af vikingetidens grubehuse skal tolkes som badstuer. Således er et ca. $5 \mathrm{~m}$ langt grubehus på Lindholm Høje blevet tolket som en badstue til svedebad. ${ }^{13}$ I husets ene ende var rester af en ovn i form af røgsværtede sten og ler og bag ovnen en kanal eller skorsten op til det fri. Ved et vikingetids gårdsanlæg i Hvítárholt i Island er et grubehus ligeledes tolket som en mulig badstue på grund af en afløbsrende fra huset og resterne af en primitivt opbygget stenovn i husets hjørne. ${ }^{14}$ Små stolpehuller langs to af væggene er formentlig spor af vægbænke. I huset fandtes knytnævestore, varmepåvirkede sten. Udgraverne foreslår, at disse efter at være opvarmede på ovnen er blevet sænket ned i trækar med vand for at varme vandet op. Med udgangspunkt $\mathrm{i}$ tolkningen af disse to grubehuse kan et lignende grubehus fra Århus med hjørneovn og vægbænke muligvis også tolkes som en badstue. $^{15}$ 


\section{Badstuernes udbredelse i det middelalderlige Danmark}

Ifølge Hugo Matthiessen fandtes der i løbet af middelalderen badstuer på slotte og i rige borgerhjem, samt på klostre og hospitaler. For folket var der offentlige badstuer i købstæderne. ${ }^{16}$ For at kunne udtale sig mere konkret om den reelle udbredelse af badstuer i det middelalderlige Danmark må man først og fremmest studere de skriftlige kilder og stednavnemateriale. Arkæologisk er der som nævnt kun konstateret sikre rester af én middelalderlig badstue - nemlig den såkaldte Mogens Tuesens badstue i Næstved fra omkring år 1484. Dertil kommer rester af et stenlagt gulv fra en badstue ved Koldinghus, som kan føres tilbage til slutningen af 1500-tallet. Når disse bygningslevn kan fastslås at være badstuer, er det hovedsageligt baseret på skriftlige kilder, der kan henføres til de konkrete bygninger. At badstuer er så svære at konstatere arkæologisk skyldes, at badning er en aktivitet, der ikke afsætter sig fysiske spor i samme grad som håndværksvirksomhed, handel eller blot almindelig husførelse. Sporene af selve badet forsvinder, når badegæsterne har forladt bygningen, og badevandet er ledt bort. De øvrige aktiviteter omkring badet, som kunne efterlade arkæologiske levn - opfyring i ovn, indtagelse af mad og drikke, evt. åreladning, kopsætning og klipning - er alle aktiviteter, som også kunne foregå uden for badstuerne og altså ikke kan tages som entydige beviser for eksistensen af en badstue. Når det alligevel er muligt at udtale sig om badstuers eksistens og udbredelse i dansk middelalder, skyldes det, at der forholdsvis ofte omtales badstuer eller relaterede emner i en række meget forskelligartede tekster - fra litterære tekster til juridiske dokumenter. Hertil kommer stednavnemateriale, der kan afsløre eksistensen af badstuer i tidligere tider.

\section{Badstuer omtalt i skriftlige kilder}

De ældste, skriftlige omtaler af badstuer i Danmark findes i Saxos »Gesta Danorum« 14. bog, der omhandler stridighederne mellem Svend, Knud og Valdemar samt Absalons bedrifter. Der er altså tale om begivenheder, der tidsmæssigt ligger tæet på Saxos egen samtid omkring år 1200. Kort før gæstebudet og brodermordet i Roskilde fortæller Saxo, at Valdemar tog til Odense for at bade, underforstået i en badstue. ${ }^{17}$ Senere besøger Svend en stormandsgård uden for Roskilde, og da han er forsinket i sin tilbagekomst til Roskilde, undskylder hans vært det med, at Svend er blevet dårlig af røgen og dampen i badet. ${ }^{18}$ Igen er der underforstået tale om en badstue, og det ses, at det drejer sig om et svedebad. Formentlig er der også tale om en badstue, når Saxo senere nævner, at Absalon tager bad på sin borg i København og hører mændene udenfor tale om fjendtlige skibe, der nærmer sig. ${ }^{19}$ Disse indirekte omtaler af 
badstuer er dog ikke tilstrækkeligt belæg for eksistensen af konkrete badstuer, f.eks. på Absalons borg, men den ukommenterede omtale af dem hos Saxo viser, at badstuer ikke har været et usædvanligt fænomen for overklassen på Saxos tid.

De tidligste omtaler af konkrete badstuer findes i kilder fra 1260'erne. I forbindelse med Peder Olafsen af Karises testamente fra 1261 er der bevaret en samtidig optegnelse over det testamenterede gods. Heri nævnes to gårde i Store Heddinge med løst og fast samt en badstue. ${ }^{20}$ I et testamente fra 1269 fremgår det, at Erland, ærkedegn i Lund, til oprettelsen af et alter i domkirken og aflønning af en præst ved alteret testamenterer en lang række gods, bl.a. en grund i Lund på hvilken, der lå en badstue. ${ }^{21}$ Badstuen i Store Heddinge var formentlig en offentlig badstue, idet der nævnes en årlig indkomst på 8 mark fra badstuen. Badstuen i Lund har formentlig været privat, idet det nævnes, at den benyttes af ærkedegnen sammen med fæller og tjenestefolk.

Konkluderende kan det siges, at det hos Saxo antydes, at private badstuer var et kendt fænomen allerede før år 1200. Både offentlige og private badstuer kendes med sikkerhed fra kilderne fra omkring 1260. Som det vil fremgå i det følgende, giver de skriftlige kilder sikre belæg for offentlige badstuer i købstæder fra omkring år 1300, men da badstuerne her omtales næsten tilfældigt, kan fænomenet sagtens være noget ældre.

\section{Badstuer i købstæder}

Indirekte omtale af en offentlig badstue i Flensborg kendes fra 1295 fra en tillægsforordning til Flensborg stadsret, der fastslår, at kvindernes badedage er mandag og torsdag, og hvis en mand bader sammen kvinderne, skal han som straf bøde med sit tøj. ${ }^{22}$ Der må her være tale om bade i offentlig badstue. I Lund nævnes 1309 en badstue af sten, der også må tolkes som offentlig, idet den anvendes til stedsangivelse, hvilket man næppe ville gøre, hvis badstuen blot havde været et udhus på en privat gårdstomt. ${ }^{23}$ Det samme er tilfældet med den badstue i Hersegade i Roskilde, som nævnes i $1314 .{ }^{24}$ Herefter forekommer badstuer forholdsvis hyppigt i dokumenter fra resten af middelalderen, uden at det dog altid er muligt at afgøre, om der er tale om private eller offentlige badstuer. I visse dokumenter er badstuen væsentlig for indholdet f.eks. i forbindelse med overdragelse af en badstue. I andre kilder nævnes en badstue blot ved en tilfældighed, f.eks. til geografisk stedfæstelse af en anden gård eller grund.

Ser man på middelalderen som en samlet periode, er der belæg for badstuer $i$ et stort antal af købstæderne i de skriftlige kilder gennem direkte omtaler af 
badstuer, udstedelsen af sjælebade samt forekomsten af stednavne med badstue. Således er der dokumentation for, at der har været badstuer i mindst 25 af de middelalderlige, danske købstæder. ${ }^{25}$ Den store udbredelse af sikre badstuer i købstæderne gør det rimeligt at antage, at der også har eksisteret badstuer i flere af de købstæder, hvor der ikke er bevaret skriftligt belæg for dem. Således må det betragtes som tilfældige lakuner, at de skriftlige kilder ikke omtaler badstuer i byer som Aalborg, Kalundborg og Helsingør.

Af de mange handler og overdragelser af badstuer, som kilderne bekræfter, står det klart, at det var en lukrativ forretning at eje og drive en badstue. At testamentere eller donere en badstue til kirken har dermed været en betydelig godgørende gerning.

Hvad angår ejerskabet af de badstuer, som var åbne for offentligheden, kan der i kilderne konstateres en tendens til, at badstuerne var ejede af enten private borgere eller af kirkelige institutioner. Badstuerne er ofte omtalt i forbindelse med ejerskifte, og ikke sjældent er det private (borgere, borgmestre, rådmænd eller gejstlige), der donerer eller testamenterer badstuer til kirkelige institutioner. ${ }^{26}$ Dermed er så godt som alle kendte offentlige badstuer i det middelalderlige Danmark i hvert fald på et tidspunkt ejet af domkirker, bykirker eller kapeller og kannikker ved disse. ${ }^{27}$ At også klostre kunne eje badstuer, kendes der i hvert fald fire eksempler på. ${ }^{28}$ En særstilling blandt badstueejende institutioner udgjorde helligåndshusene, som ikke var egentlige kirkelige institutioner tilknyttet en bestemt orden, men private stiftelser. Helligåndshusets badstue i København var således privat ejet, og ligeledes ejede også Helligåndshuset i Lund en badstue i Malmø. Der ses flere eksempler på, at kirkeligt ejede badstuer udlejedes til borgere mod, at disse betalte afgift til ejeren og opfyldte visse betingelser. Kirkelige institutioner har således ejet, men ikke nødvendigvis selv drevet flertallet af badstuerne. Den badstue, som i 1403 sælges til Ribe by, er det eneste danske eksempel på, at en by i middelalderen ejede og drev en badstue. Det faktum, at den overvejende del af de kendte danske badstuer ejedes af kirkelige institutioner, kan synes at stå i kontrast til forholdene i Tyskland, hvor det var fyrsten eller byens øvrighed, der havde retten til at drive badstuer og kunne forpagte badstuerne til private badstuemænd. ${ }^{29}$ Lizzie Carlsson argumenterer for, at købstædernes øvrighed i Sverige oprindeligt havde samme privilegier. ${ }^{30}$ For de danske forholds vedkommende kan det dog være et spørgsmål om kildematerialets repræsentativitet, idet kirkeligt forvaltningsmateriale helt klart er det bedst bevarede. Derfor er det muligt, at også danske købstæder har stået for badstuedrift, selv om det ikke er veldokumenteret i kilderne. 


\section{Badtyper i middelalderlige badstuer}

Det er væsentligt ud fra de skriftlige kilder at definere hvilke badtyper, der eksisterede i Danmarks middelalder, dels for at kunne tolke arkæologiske fund og dels for at kunne vurdere om man med rimelighed kan drage paralleller til arkæologiske fund og historiske forhold omkring badekulturen i andre lande.

Ser man specifikt på det danske område, er det vanskeligt at føre bevis for, om henholdsvis karbade og svedebade var udbredt her, og om de begge anvendtes i badstuerne. Dette skyldes dels, at de middelalderlige kilder sjældent er detaljerede i omtalen af bade, og dels at faglitteraturen om emnet tit omtaler bade i uklart afgrænsede geografiske områder og tidsmæssige epoker. I den omtale, man finder i »Kulturhistorisk leksikon for nordisk middelalder« af badning i Danmark, Norge og Sverige, står blot: „Badstuer på land og i by samt naturbade benyttedes regelmæssigt. ${ }^{31}$ I sin beskrivelse af badstuernes brug $\mathrm{i}$ 1500-tallet er Troels-Lund også noget uklar, idet han skriver: „Et særskilt badekar synes ikke at have været aldeles nødvendigt, men fandtes vistnok ofte. [...] Badekar benyttedes langtfra altid. ${ }^{32}$

I de tilfælde, hvor de skriftlige danske middelalderkilder faktisk giver oplysninger om badtyper, er der tale om svedebade. Saxo skriver som nævnt, at kong Svend tilsyneladende skulle have fået hovedpine af dampen i badstuen. ${ }^{33} \mathrm{Be}-$ skrivelsen af badstuebad hos lægen Henrik Harpestreng er også et tørt bad, hvor badegæsten først får varme og svedning og senere overøses med koldt vand. ${ }^{34}$ I et jærtegn omkring Erik Plovpenning fra anden del af 1200-tallet omtales en mand, der efter badet tvætter sig i havet, hvilket også tyder på, at selve badet har været et tørt bad og ikke et karbad. ${ }^{35}$ Mest entydigt er lighedstegnet mellem badstuebad og svedebad i et dokument fra Slesvig i 1452, ifølge hvilket biskop Nikolai Wulff betaler for, at fattige fra helligåndshospitalet hver 14. dag kan få bad. Det nævnes udtrykkeligt, at badet skal foregå i en badstue og inkludere badning, klipning og vaskning samt, hvad der ellers hører til badet. Derefter nævnes det, at hvis et badstuebad ikke er muligt, skal der i stedet foranstaltes et karbad til de fattige. ${ }^{36}$ Svedebad med efterfølgende afvaskning er altså den gængse form for bad, mens karbade kun er en alternativ mulighed i mangel på svedebade.

Omtaler af badekar optræder fortrinsvist i skriftlige danske kilder fra seneller eftermiddelalderen, og det er altid i forbindelse med omtaler af private hjem eller klostre. Eksempelvis nævnes ingen badekar i de ellers udførlige bohaveoptegnelser i »Testamenter fra Danmarks Middelalder indtil 1450«. Muligvis skal det løfuekar, som præsten Peder Pedersen borttestamenterer i 1521, opfattes som et badekar, men der kan også være tale om et vaskefad. ${ }^{37}$ I Gråbrødre Kloster i København findes i 1530 fem løvekar. ${ }^{38}$ I inventariet fra 
badstuen på Koldinghus 1585 nævnes et lille og et stort badekar. I en københavnsk retssag fra 1595 nævnes det, at nogle af de involverede parter har været i karbad sammen i et privat hjem. ${ }^{39}$ Et karbad har ikke i samme grad som et svedebad fordret en selvstændig bygning med specifik indretning, idet et karbad kunne tages alle steder, hvor et tilpas stort kar kunne opstilles, og hvor der var adgang til opvarmet badevand, f.eks. i et køkken.

Der er altså samlet set kun et meget lille grundlag for at udtale sig sikkert om badtyper i middelalderens Danmark. De skriftlige kilder antyder, at dampeller svedebade har været $\mathrm{i}$ brug i første halvdel af middelalderen, mens skriftlige belæg for karbade først kendes i senmiddelalderen og nyere tid. Den antydede udvikling i badtyper fra svedebade til karbade kan dog være et resultat af tilfældigheder i de overleverede kilder, og i hvert fald er det næppe rigtigt, at karbade først kendes i Danmark fra 1500-tallet. Sandsynligvis har de to badtyper eksisteret side om side. I det tyske område var svedebade den udbredte badeform i de offentlige badstuer, hvorimod karbade først og fremmest var knyttet til klostre og adelen og blev forbundet med en særlig fornem form for renselse. ${ }^{40}$ Vurderet ud fra skriftlige kilder var karbade ikke et ukendt fænomen i de tyske badstuer i middelalderen, men synes underordnet svedebadet. ${ }^{41}$ En simpel forklaring på dette er måske også, at karbade var mere omkostningskrævende end svedebade. I det tyske område fremgår det af en bevaret badeforordning fra Bamberg i 1480, at et karbad blev takseret mindst seks gange højere end et svedebad. ${ }^{42}$ Muligvis har en lignende skelnen mellem det mere almindelige svedebad og det finere og mere omkostningskrævende karbad eksisteret i dansk middelalder. Tyske badstueforskere anfører, at karbade først blev almindelige i det tyske område i løbet af 1500-tallet og eftermiddelalderlig tid i forbindelse med opblomstringen af kurbade og Wildbäder (bade i det fri) - en udvikling, der ikke findes paralleller til i Danmark. ${ }^{43}$ Middelalderlige illustrationer af personer, der tager karbad, skal derfor formentlig snarere tolkes som idealforestillingen om en badstue end som en afbildning af det gængse badstuebad. I nogle tilfælde er der heller ikke tale om afbildninger af badstuer, men horehuse. Dette gælder for en burgundisk illustration fra ca. 1470, der af og til er anvendt i faglitteratur som et billede på middelalderens brogede badstueliv (se fig. 1) ${ }^{44}$ Billedet bringes imidlertid løsrevet fra sin sammenhæng, idet det er en illustration til en fransk oversættelse af et romersk skrift, i hvilket forfatteren Valerius Maximus præsenterer den romerske kejser for alle de laster, der har vundet indpas i kejserriget, bl.a. ved at tage ham til et badebordel. ${ }^{45}$ Valerius og kejseren ses på illustrationen i middelalderlige klædedragter, men situationen er fra antikken, og det er ingen gæengs middelalderbadstue, der afbildes. 


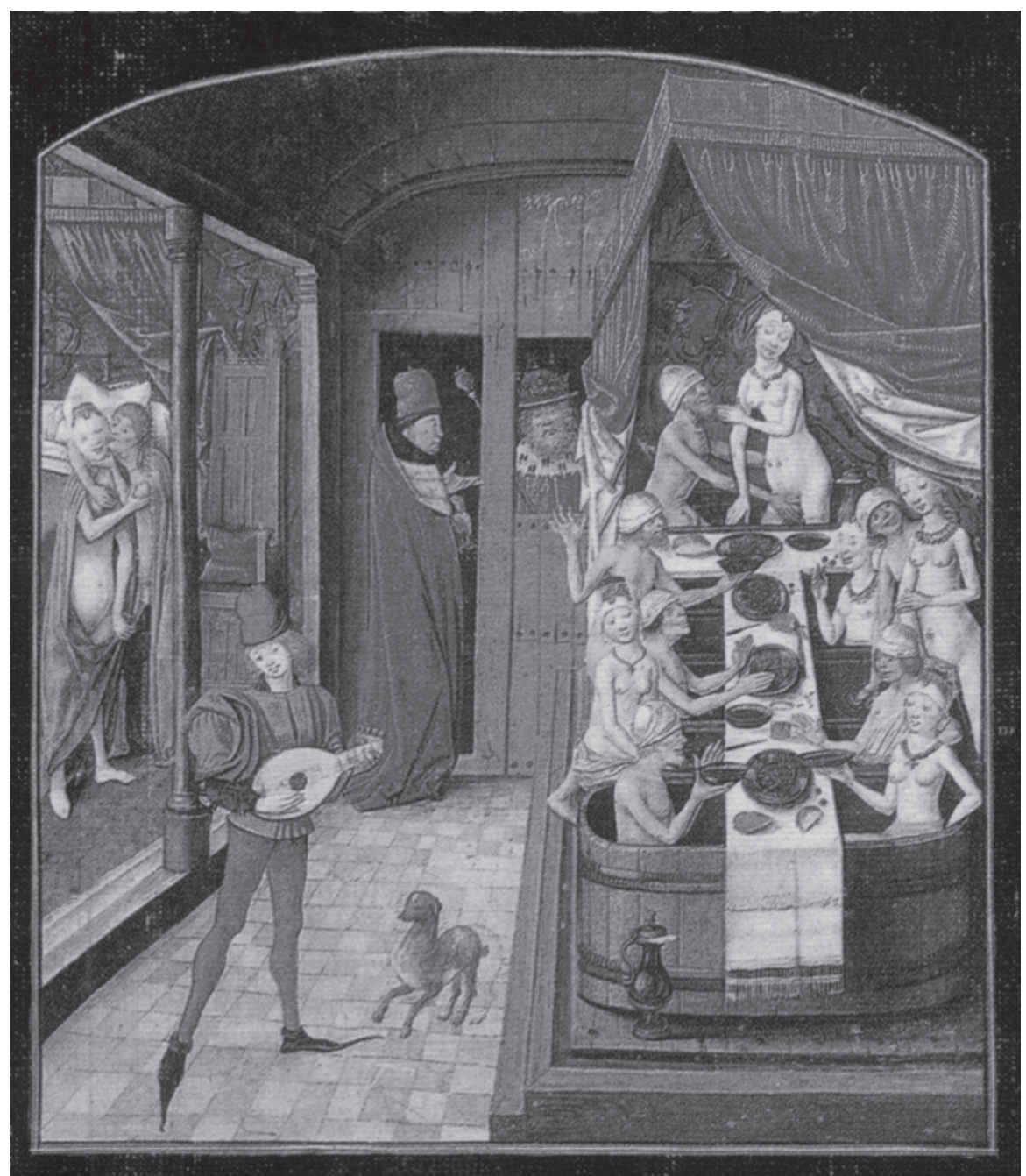

Fig. 1. Scene fra badebordel i burgundisk manuskript fra ca. 1470. Det er ikke en almindelig middelalderlig badstue, der afbildes. - Original i Bibliothèque Nationale, Paris. Efter Duerr 1994.

Scene from a bathing brothel on a Burgundy manuscript from c. 1470. This is not an ordinary medieval bath-house

Ud fra de gennemgåede kilder vurderes det rimeligt med forsigtighed at anvende tysk og svensk materiale som parallelmateriale til det danske, når det drejer sig om svedebade i offentlige badstuer. Derimod vil der ikke umiddelbart kunne drages paralleller mellem tyske kurbade og islændingenes brug af varme kilder og dansk badekultur i middelalderen. 


\section{Svedebade}

Der findes ingen skriftlige kilder fra dansk middelalder, der i detaljer beskriver, hvordan et badstuebad foregik, mens der fra det tyske område er bevaret adskillige litterære tekster og en lang række middelalderlige illustrationer, der giver detaljerede oplysninger om dette. Det er rimeligt at antage, at forholdene i de tyske badstuer i al væsentlighed har lignet forholdene i de danske badstuer. Forløbet af et svedebad gennemgås minutiøst i et tysk digt fra slutningen af 1200-tallet, og hovedtrækkene er de følgende: ${ }^{46}$ Når badstuen var varmet op og evt. røg fra ovnen ledt ud, gav badstuemanden signal om, at badstuen var klar gennem råb, hornsignal eller ved at hænge et skilt ud. Dette skilt kunne have form af en såkaldt badekvast - et birkeris, som anvendtes under badet -

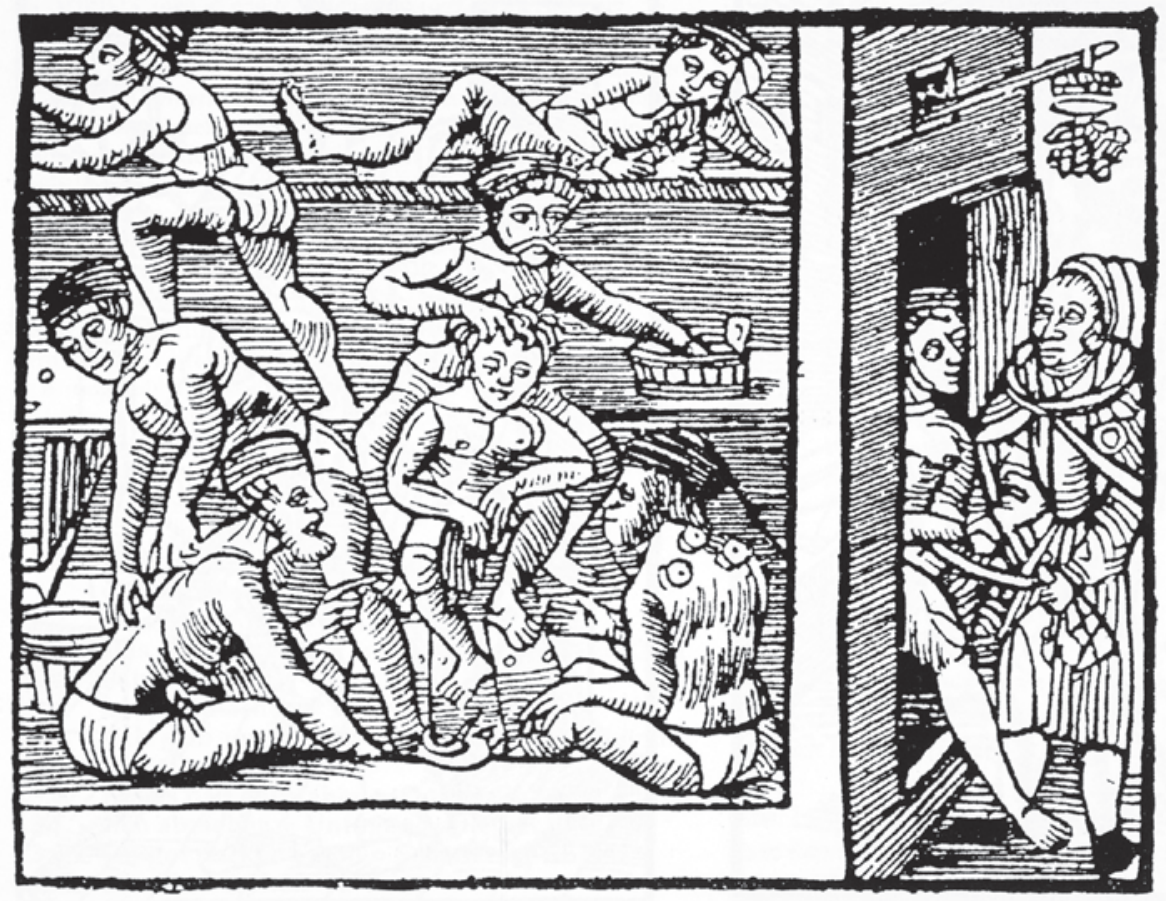

Fig. 2. Jødisk badstue, der næppe har været væsentligt forskellig fra andre badstuer. Mændene tager svedebad liggende på vægbænke i flere niveauer, mens badstuens personale foretager hårvask og kopsætning. Over indgangsdøren er en badekvast hængt op som tegn på, at badstuen er åben. - „Der Juden badstub« træsnit af Philipp von Allendorf, 1535. Efter Tuchen 2003.

Jewish bath-house, which was probably not substantially different from other bath-houses. Men taking sweat baths lying on wall benches at various levels while the bath-house staff wash their hair and cup blood from their bodies. Above the door, a bundle of birch twigs indicates that the bath-house is open. 


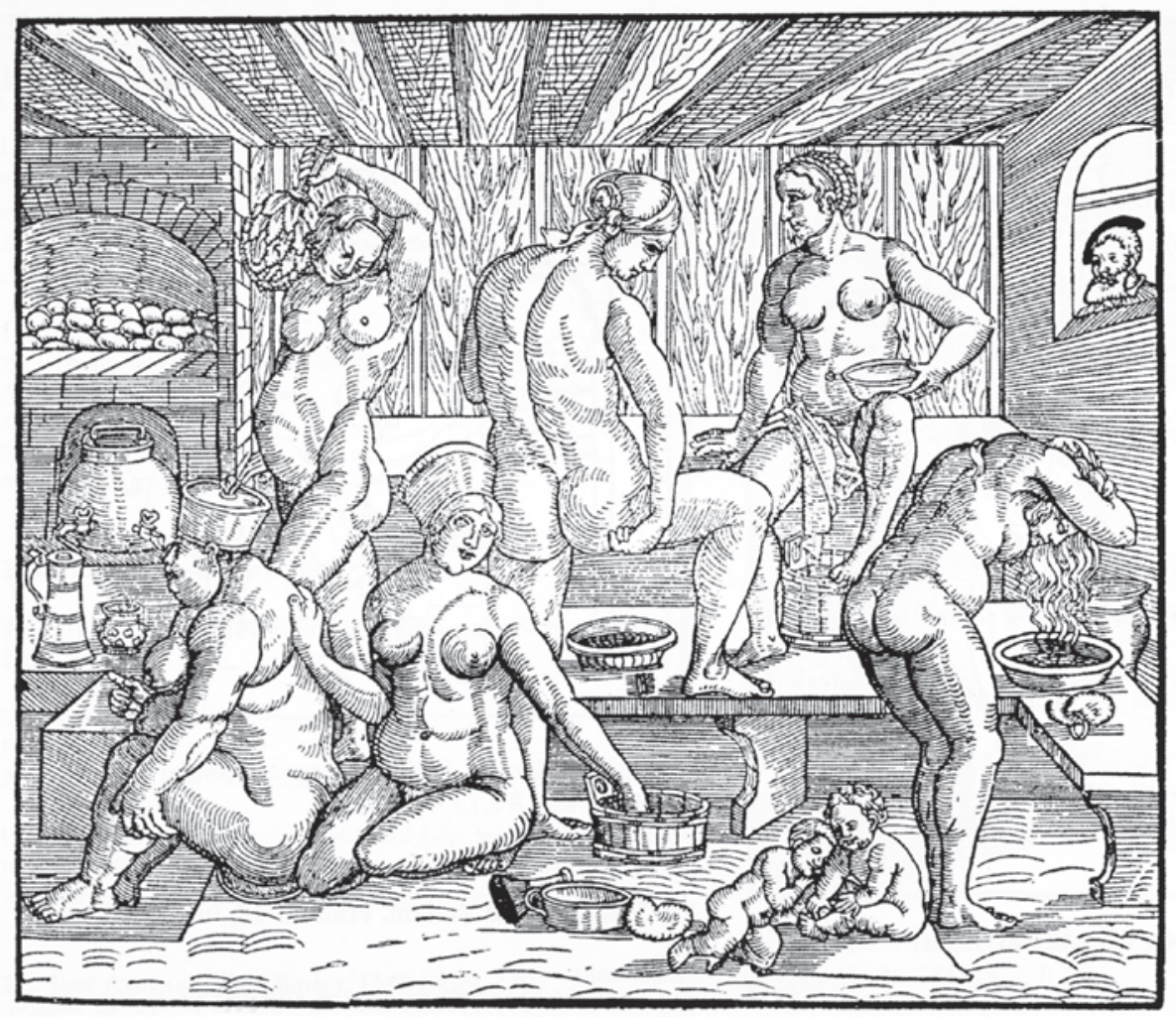

Fig. 3. Kvinder i badstue. En kvinde benytter sig af en badekvast, mens andre under svedebadet vasker deres kroppe og hår med vand fra træbaljer eller bækkener. I baggrunden til venstre ses badstueovnen med stenpakning og varmtvandskedel. - Træsnit af Hans Sebald Beham, ca. 1540. Efter Tuchen.

Women in a bath-house. One woman uses a bundle of twigs while others wash their bodies and hair with water from wooden bowls or metal pans. In the background the bathhouse stove with its covering of granite boulders and a kettle can be seen.

eller af et vaskebækken (fig. 2). Sådanne bækkenformede skilte er i nyere tid blevet et kendetegn for barbererhvervet. Badegæsterne kunne gå til badstuen påklædte eller i en lettere dragt, som anvendtes til formålet. Sandsynligvis er badelagener, som kendes fra middelalderlige, danske testamenter, sådanne klædningsstykker. ${ }^{47}$ Der kan dog også være tale om en let dragt, som man bar i selve baderummet, eller når man kølede af efter svedebadet. Ved ankomsten til badstuen klædte man sig af $i$ et forrum, hvorefter man blev overhældt med lunkent vand og slået med en badekvast. Dette skete dels for at fjerne snavs, dels for at åbne hudens porer og vænne kroppen til badstuens varme. Derefter 
gik man ind i selve baderummet, i hvilket der dannedes damp ved at slå vand på badstueovnen. (fig. 3)

Ovnen var et essentielt inventar i badstuerne og kunne have forskellig udformning. Karakteristisk var dog en overdel eller et magasin med sten, som ved opfyringen blev kraftigt opvarmede og lagrede varmen. Herved kunne badet foregå enten ved tør strålevarme, eller man kunne slå vand på de varme sten og danne hede vanddampe. De badende sad eller lå på bænke, der var opført langs væggene, og som kunne være trindelte. Under badet kunne man vaske sig med lud eller sæbe og vand fra træbaljer (fig. 3).

Efter svedebadet overøste man sig med koldt vand for at fjerne sved, snavs og evt. lud. Fra tyske tekster og illustrationer kendes det, at denne afskylning kunne ske »vor der Tür» (fig. 4) eller i badstuens forrum. I de tyske badstuer, som kunne bestå af adskillige rum, var det ikke ualmindeligt, at man efter badet hvilede sig i dertil opstillede senge.

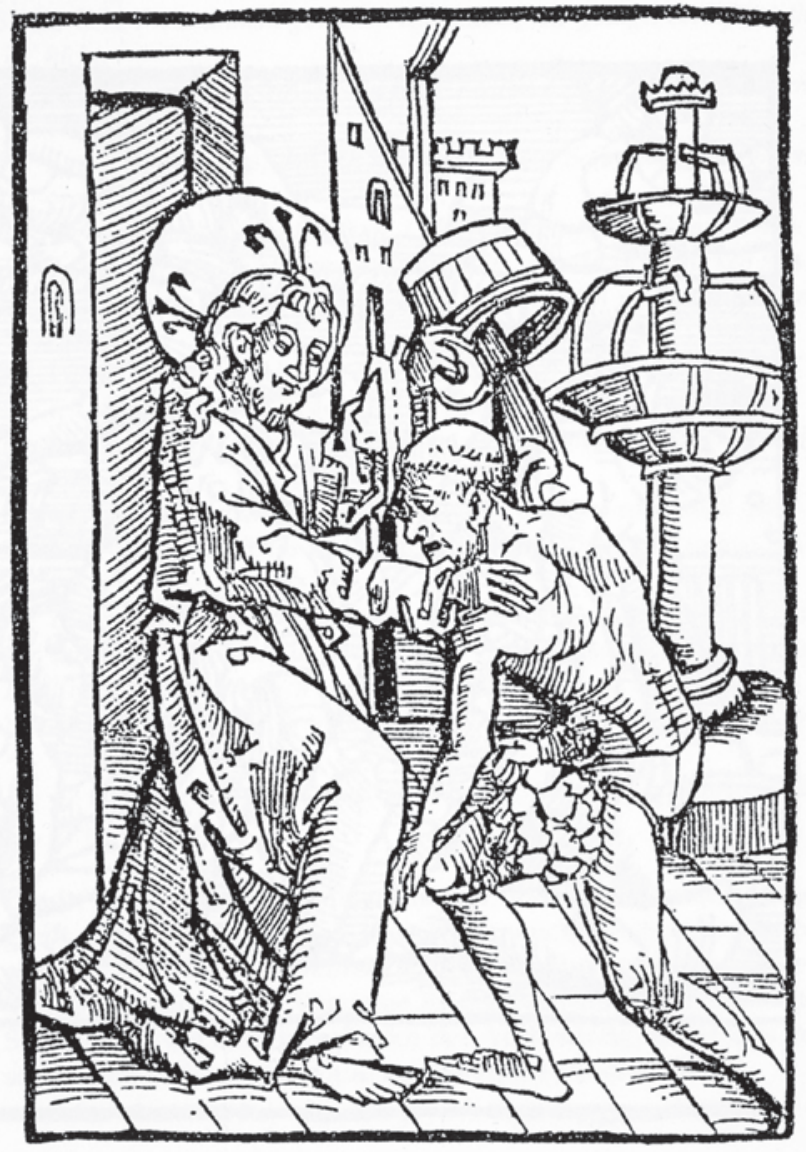

Fig. 4. Afskylning efter svedebadet foregår uden for badstuen. Træsnit af Thomas Murner fra "Ein andechtig geistlich Badenfahrt« 1514. Skriftet er en allegorisk gengivelse af en badstuegang, hvor Jesus er badstuemand og dermed renser mennesket for dets synder. - Efter Tuchen 2003.

Rinsing after the sweat bath took place outside the bath-house. Woodcut from an allegoric text in which Jesus is the bathhouse keeper washing away sins. 


\section{Badstuebade i middelalderens lægekunst}

Badstuebade udgjorde en vigtig faktor i middelalderens opfattelse af helse og sundhed, og badenes effekt opfattedes ikke blot som en hygiejnisk foranstaltning, men i lige så høj grad som sygdomsforebyggende og -bekæmpende. Egentlige læger var yderst få og forbeholdt samfundets top. Kannikken og reformatoren Christiern Pedersen nævner i fortalen til »Nøttelig Legebog faar Fattige og Rige, Unge og Gamle« fra 1533, »at her ikke ere mange Doctere eller Mestere i Lægekonst i disse Land og Rige, som den menige Mand læge eller hielpe kunde ${ }^{48}$ Sundhedsvæsenet og sygeplejen i praksis var derfor et anliggende for klostre og andre kirkelige institutioner.

Kirkens holdning til badning var dobbelttydig. I tidlig middelalder blev badning forbundet med nydelse og skulle dermed undgås. ${ }^{49}$ Senere i middelalderen ses det, at sjælebade for fattige fremstod som en entydigt god kristen gerning, mens det samtidig syntes ønskeligt, at munke og nonner selv forholdt sig asketisk til denne nydelse lige som til andre dele af jordelivet. Det fremhæves således som et fromhedstegn helt at afstå fra badning, f.eks. skulle biskop Reginard af Lüttich aldrig have badet, og den hellige Elisabeth erklærede efter at have dyppet en fod i vandet, at nu var hendes bad overstået. ${ }^{50}$ Samtidig har klostrene ikke været uvidende om badstuernes sundhedsfremmende effekt, som det verdslige samfund kendte til. I Benedikts regel, som flere andre klosterregler byggede på, opfordres til mådeholdent brug af bade, mens det fremhæves, at syge munke skal bade efter behov. ${ }^{51}$ Lignende bestemmelser findes i den hellige Birgittas regler fra senmiddelalderen. ${ }^{52}$

Også i det verdslige miljø blev badstuebadet betragtet som en vigtig foranstaltning for at holde legemet raskt, hvilket ses af middelalderlige lægeskrifter. Fra det nordiske område er bevaret en række afskrifter af middelalderlige, lægelige tekster, der menes at være forfattede af den danske læge Henrik Harpestreng, som døde i 1244. Man ved kun lidt om Harpestrengs liv, men han omtales som magister, kannik i Roskilde og læge for Erik Plovpenning. ${ }^{53}$

Harpestrengs mest kendte værker er to urtebøger på henholdsvis latin og dansk. Disse bygger dels på udenlandske kilder, dels indeholder de kapitler, som, man mener, er forfattede af Harpestreng selv. Brugen af badstuer omtaler Harpestreng i en række medicinsk-hygiejniske og kirurgiske stykker, der i håndskrifterne som regel følger umiddelbart efter urtebøgerne, men som muligvis oprindeligt har været et selvstændigt værk. ${ }^{54}$ De åreladningsregler, der beskrives i disse tekster, har en del til fælles med udenlandske værker, mens et direkte forlæg for Harpestrengs omtale af badstuebrug ikke synes at være konstateret. ${ }^{55}$ Der findes forskellige afskrifter af Harpestrengs 
omtale af badstuer, hvis datering er omdiskuteret, men som med sikkerhed kendes fra i hvert fald 1400-tallet. De forskellige afskrifter er for øvrigt næsten enslydende. ${ }^{56}$

Badstuebad anbefales af Harpestreng til dem, som har kolde, torre og skarpe legemer - med skarpe menes formentlig skorpet, sprukken hud eller lignende. I badstuen vil kroppen fă fugtighed og varme gennem svedning, men man skal agte sig for at svede for meget, da kroppen ellers vil blive mere udtørret end før. Efter svedebadet skal man vaske sig i koldt, ikke varmt vand. Harpestreng opremser derefter fordele og ulemper ved badstuebade. Et besøg i badstuen væder legemet, åbner svedporer, vasker urenheder af, udskiller uønskede væsker fra kroppen, gør tykt blod tyndt, lindrer mavepine og fremmer søvn for den trætte. På den anden side kan overdreven brug af badstuen mindske legemets styrke og give kvalme. For nogen kan badstuen gøre deres hjerte så hedt, at de dåner eller næsten omkommer, og derfor skal de, der har feber, sår, bylder eller knuste ben, helt undgå badstuen. Ligeledes skal man ikke gå i badstue umiddelbart efter at have spist, da man »deraf fanger fedme«. Også efter et badstuebad bør man hvile sig inden indtagelse af mad og drikke. Den, som har indtaget medicin (lægeurter), skal på andendagen søge badstue, for at de væsker, som er løsnet fra kroppen gennem medicinen, kunne udskilles fra kroppen i den meget hede badstue. Bagefter skulle man indtage et måltid af bygsuppe.

Harpestrengs anbefalinger af badstuebad er et direkte udtryk for den middelalderlige, katolske kirkes sygdomsopfattelse, der byggede på antikkens humoralpatologi, hvis essens er læren om de fire væsker, som kroppen mentes at indeholde: blod, slim, sort galde og gul galde. Hos et raskt menneske er der balance i forholdet mellem disse væsker, mens en indbyrdes ubalance i væskerne resulterede i sygdom. Logikken i teorien var, at sundhedstilstanden kunne genoprettes ved atter at bringe væskerne i balance. Overflødig og dårlig væske kunne udtømmes af kroppen ved at fremprovokere opkastning, sved, afføring eller vandladning. Et overskud af blod i kroppen kunne udtømmes via åreladning. Man behandlede symptomer med deres modsætning, varmt blev behandlet med koldt, tørt med vådt. Således ses det, at Harpestreng anbefaler folk med kolde og tørre kroppe at besøge den varme og fugtige badstue for at få genoprettet kroppens balance, samt at svedningen i badstuen forstærkede den udskilning af kroppens overflødige væsker, som kunne fremprovokeres ved hjælp af lægeurter. Set i denne sammenhæng er det rimeligt at formode, at man i middelalderen ikke kun har betragtet badstuer som badeanstalter for den personlige hygiejne, men også som led i bekæmpelsen af sygdomme. 


\section{Yderligere tjenester i badstuerne}

Ud over selve badet havde badstuerne også andre tilbud til gæsterne. Fra det danske område er der ikke bevaret detaljerede oplysninger om disse tjenester, og det er derfor igen relevant at se på tyske, historiske kilder og billedmateriale. Heraf fremgår det, at man i badstuerne foretog klipning, åreladning, kopsætning, udtrækning af tænder, behandling af sår og sammensætning af brækkede knogler.

Klipning og barbering foretoges også uden for badstuerne, nemlig hos barbererne, som også kunne konkurrere på de kirurgiske indgreb, som badstuerne tilbød. Først i eftermiddelalderlig tid fremkommer et egentligt kirurgisk erhverv. Fra Tyskland kendes fra 1568 værket "Ständebuch«, i hvilket en lang række erhverv i datidens samfund præsenteres med et træsnit af Jost Amman og et digt af Hans Sachs (fig. 5). Heri fremgår det, hvad badstuemandens erhverv består i. ${ }^{57}$ Han giver fattige som rige svedebade, skrubber dem, vasker og klipper deres hår, årelader og kopsætter samt behandler dem for utøj (fig. 6). I samme værk nævnes barberens arbejdsområder at være behandling af sår

Fig. 5. En badstuemand er ved at kopsætte to af badstuens gæster. - Træsnit af Jost Amman fra Ständebuch, 1568.

A bath-house keeper cups two guests.

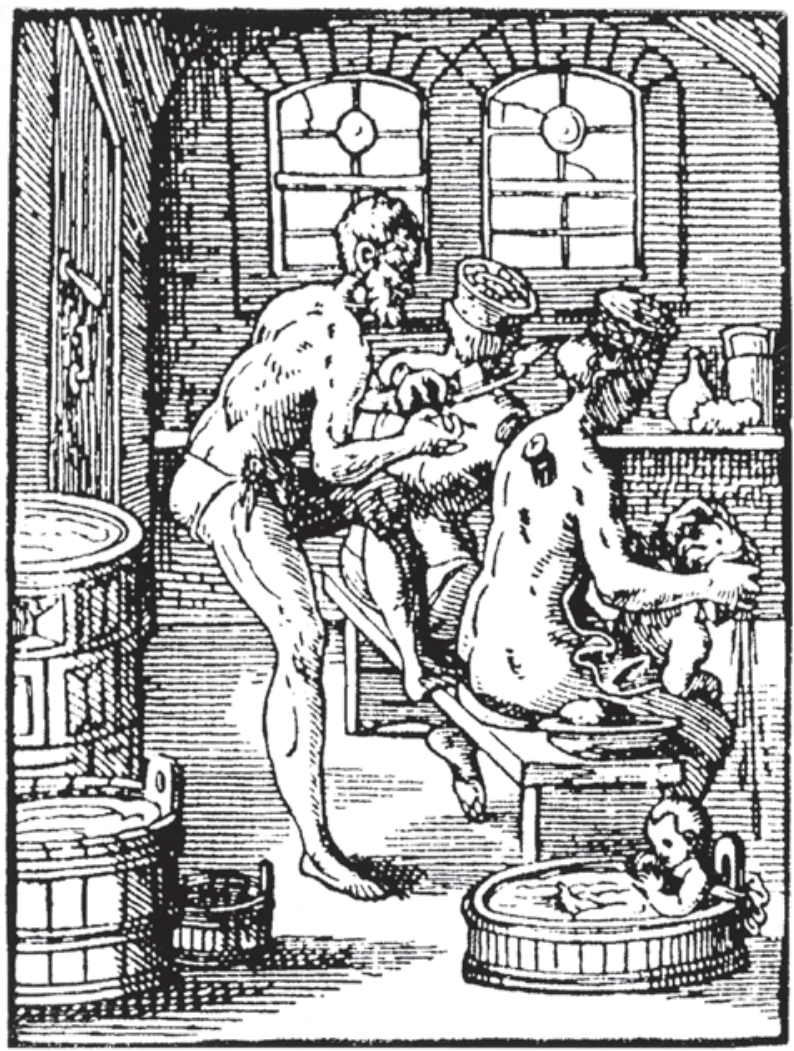




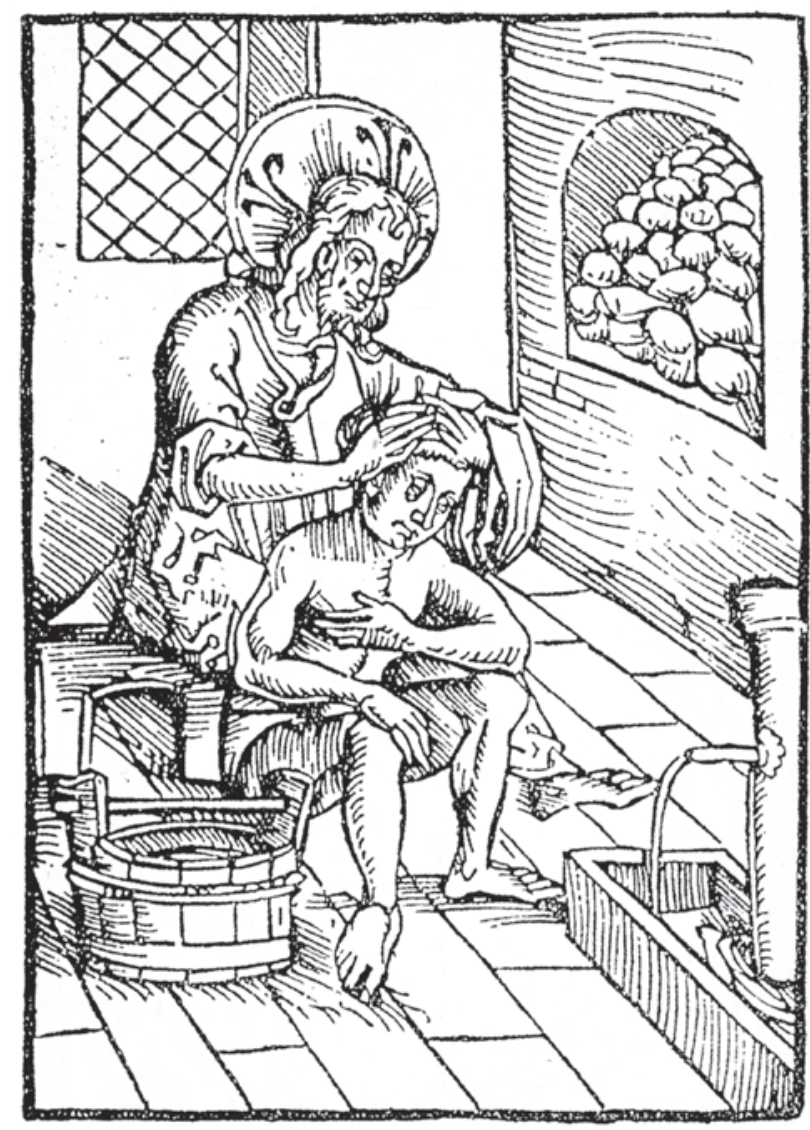

Fig 6. Hårvask i en badstue. I baggrunden ses badstueovnen med stenpakning. For forklaring om billedets herkomst se fig. 4. - Efter Tuchen 2003.

Washing hair in a bathhouse. In the background the bath-house stove can be seen with its covering of stones.

og knoglebrud, fransoser og øjensygdomme, udtrækning af tænder, klipning og barbering samt åreladning. ${ }^{58}$ Der er altså et vist sammenfald mellem de to faggruppers tjenester.

\section{Badstuemænd og barberer i det middelalderlige og efterreformatoriske Danmark}

Med baggrund i den viden, de tyske kilder giver, er det muligt af få et indtryk af forholdene i Danmark, hvad angår badstuemændenes og beslægtede faggruppers virkeområder. Ved at se nærmere på kildernes specifikke stillingsbetegnelse samt ved at sammenligne med eftermiddelalderlige kilder er det rimeligt at konkludere, at badstuerne i det middelalderlige Danmark har tilbudt samme tjenester, som kendes fra vores nabolande.

I danske, senmiddelalderlige kilder forekommer såvel badstuemænd og -koner, som bartskærere og barberer. Disse forskellige stillingsbetegnelser synes at dække over forskellige virkeområder, men overgangen mellem de forskel- 
lige faggrupper har sandsynligvis været flydende, ligesom barber og bartskærer (eller badskærer) må betragtes som synonymer.

I dronning Christines hof holdningsregnskaber nævnes henholdsvis en badstuekone og en badstuemand i Odense, som anretter sjælebade på dronningens ønske, og disse personer må ud fra deres stillingsbetegnelse være specifikt knyttede til badstueinstitutioner. Det samme er tilfældet med Claus Badstuemand i København, der nævnes i Roskildebispens jordebog omkring 1370, ligesom Poul Badstuemand, der i begyndelsen af 1500-tallet ifølge Roskilde Domkirkes regnskaber betaler afgift til kirken. ${ }^{59}$ Når dronning Christine i 1509 og 1510 bliver åreladt af henholdsvis Jacob Læge og Jacob Bartskær, ${ }^{60}$ som muligvis er samme person, kan denne operation lige såvel være foregået uden for badstuen, idet en person med stillingsbetegnelsen bartskærer ikke nødvendigvis er tilknyttet en badstue, men kan tilbyde sine ydelser, hvor der er brug for dem.

I det tidligere nævnte dokument fra Slesvig nævnes det i 1452, at klipning hører med til et badstuebad. Barberfaget i Danmark synes at have været frit indtil 1501, hvor det første barberlav i København oprettes bl.a. med bestemmelser om, at der kun må være seks mestre i byen. ${ }^{61} \mathrm{I} 1515$ får barbererne i Flensborg lavsartikler, men da disse betegnes som "nye«, har der sandsynligvis eksisteret ældre bestemmelser. Også dette lav er sluttet, og antallet af mestre i Flensborg fastsættes til fire. ${ }^{62}$ I 1528 skænker kong Frederik I badstuen ved siden af Rådhuset i Flensborg til sin barber Asmus Belle sammen med retten til forstanderskab i badernes og barberernes lav. ${ }^{63}$ Det tyder på, at barbererne og badstuemændene betragtedes som en samlet erhvervsgruppe. Der er i Danmark ikke bevaret lavsartikler for badstuemænd hverken fra middelalderen eller senere tider, og det er tvivlsomt, om sådanne overhovedet har eksisteret, idet der i købstæderne til enhver tid formentlig kun har været én eller ganske få badstuemænd ${ }^{64}$ I eftermiddelalderlig tid defineres derimod barbererne som en erhvervsgruppe med eneret til at udføre tjenester, som tidligere også badstuemændene tilbød. I Malmø-bartskærernes skrå fra 1544 fremgår det, at badstuemænd og -kvinder ikke må behandle friske eller gamle sår eller andre sygdomme, med mindre bartskærerlavet godkender dette, eller det drejer sig om sygdomme, som bartskærerne ikke selv har kunnet kurere. ${ }^{65}$ Ligeledes fastslås det i de københavnske barberers artikler fra så sent som 1684, at „Badstu-Mændene skulle alene blive ved deres Badstue og Kopsætning og ei gjøre Bartskjær-Lauget nogen Indpas i deres Kunst, enten med Barberen, Aareladen, Patienter at forbinde eller kurere, ei heller Bækkener eller Bartskjær-Skilt at udhænge ${ }^{66}{ }^{6}$ Nedfældelsen af denne bestemmelse viser, at der endnu sidst $\mathrm{i}$ 1600-tallet fandtes badstuer, hvis personale bevægede sig ind på andre faggruppers erhvervsmæssige enemærker. ${ }^{67}$ 
Mens kilderne antyder, at danske badstuer har tilbudt samme tjenester som de tyske, er det vanskeligt at skelne de beslægtede fags (badstuemænd, barberer og bartskærere) virkeområder og arbejdsopgaver fra hinanden. Graden af badstuemændenes organisering i lav, deres stilling i samfundet og faglige respekt har varieret fra sted til sted, og her kan udenlandske forhold ikke uden videre overføres til det danske område. Således er der ingen kendte danske paralleller til de tyske lav af badstuemænd, der kendes i byer som Lüneburg og Hamburg allerede $\mathrm{i}$ anden halvdel af 1300 -tallet. ${ }^{68}$

\section{Kopsætning og åreladning}

Kopsætning og åreladning var indgreb, som man i middelalderen anvendte både til at forebygge og bekæmpe sygdomme ved at komme af med det, man betragtede som overflødigt blod. Åreladning foregik ved at snitte hul på en blodåre - f.eks. på indersiden af armen ved albuen - og derved slippe blodet ud. Kopsætning skete ved at snitte et hul på huden, der hvor blodet skulle udtappes - gerne på skuldre eller ryg - og derefter sætte små, runde, opvarmede blodkopper af keramik, glas eller metal hen over snittet. Alternativt kunne også anvendes kohorn. ${ }^{69}$ Når koppen afkøledes, sugede den sig fast til huden, og det undertryk, der opstod i koppen, trak blodet ud. Der findes ikke danske kilder fra middelalderen, der omtaler kopsætning og åreladning i badstuer. Begge dele har dog med sikkerhed fundet sted i Danmark og Norden i middelalderen. I Harpestrengs tekster indgår som nævnt åreladningsregler, og også brugen af kopper omtales. ${ }^{70}$ Åreladning omtales i sagatekster og mere konkret i dronning Christines hofholdningsregnskaber, hvor det ses, at dronningen lader sig årelade flere gange. ${ }^{71}$ I en bergensisk bylov fra 1282 fastsættes den takst, byens barberer må tage for åreladning, men det er uklart, om der er tale om åreladning i badstuer eller andetsteds. ${ }^{72}$ Svenskeren Olaus Magnus skriver i »Historia om de nordiska folken« fra 1558, at kopsætning og åreladning er sikrest, når de foretages i en badstue. ${ }^{73}$ Samlet set er det rimeligt at antage, at disse tjenester også er blevet udført i badstuerne.

\section{Hvem badede i de offentlige badstuer?}

I modsætning til i dag var badning i middelalderen ofte et socialt fænomen. I private badstuer kunne en husstands medlemmer bade sammen, ligesom også venner kunne inviteres til at deltage i badet. I testamentet fra 1269 for ærkedegn i Lund, Erland Erlandsen, fremgår det, at ærkedegnen på sin grund i Lund havde en badstue, hvor han plejede at bade med fæller og undergivne. ${ }^{74}$ Af kong Hans og dronning Christines regnskabsbøger fra 1487 ses det, at kong 
Hans jæevnligt benyttede badstuen hos sin ven, købmanden Hans Bogbinder, der var en af byens rigeste borgere. Kongen fik bragt tysk øl for 3 mark til Bogbinders hus i forbindelse med et bad, mens en anden post angiver, at kongen betalte 10 mark til Bogbinders hustru for sin brug af badstuen i det forgangne år. Det sociale aspekt ved badning fremgår også af en bandlysning af ridderen Lave Rød m.fl. udstedt af jyske bisper i $1350 .{ }^{75}$ Heri hedder det, at den, som drister sig til at deltage i måltid, drikke, handel, bolig, bad eller andet med disse mænd, risikerer samme bandlysning.

I de offentlige badstuer var badning i sagens natur også et socialt fænomen. Et sprogligt vidnesbyrd om dette badstueliv er bevaret i Peder Syvs ordsprogssamling fra 1688: »Der kommer altid nyt fra badskærhus og badstue« ${ }^{76}$ De skriftlige kilder giver vidnesbyrd om, at folk fra alle samfundslag besøgte badstuerne. Kong Hans vides fra regnskaberne at have besøgt den offentlige badstue i henholdsvis Nyborg og Århus. ${ }^{77}$ Ligeledes betaler dronning Christine for et bad i Nyborg, ${ }^{78}$ og også Christoffer af Bayern og dronning Dorothea vides at have betalt for egen badstuegang, ${ }^{79}$ hvilket formentlig betyder, at disse bade har foregået i offentlige badstuer. I den anden ende af det sociale spekter forekommer donerede sjælebade til fattigfolk og peblinge, elever på byernes latinskole. Ligeledes fremgår det af samtidige regnskaber - f.eks. universitetets - at håndværkere betaltes såkaldte badstuepenge, et fænomen, der kan sammenlignes med vore dages drikkepenge..$^{80}$ Formentlig har der foregået en vis adskillelse i de tider, hvor forskellige sociale grupper har besøgt badstuerne. I hvert fald nævnes det i Slesvig i 1452, at de bade, som skal beredes for fattigfolk, skal finde sted »zu einer wolbequemen Zeit» - sandsynligvis en tid, hvor de fattige ikke ville forstyrre badstuens øvrige gæster. ${ }^{81}$ Hvorvidt fællesbadning mellem de to køn har forekommet, giver kilderne ikke grundlag for at udtale sig om. Ud over den nævnte bestemmelse fra Flensborg byret, der fastslår, hvilke dage henholdsvis mænd og kvinder må bade, er der ingen omtaler af fællesbade eller forbud mod dette fra dansk middelalder, som det kendes fra det øvrige Europa. ${ }^{82}$ Svenskeren Olaus Magnus anfæegter i 1558 i »Historia om de nordiska folken« på det kraftigste, at sådan fællesbadning skulle forekomme i Norden. ${ }^{83}$ Han henviser sådanne usædeligheder til det protestantiske Nordtyskland. Olaus Magnus' værk er dog ikke fri for at være tendentiøst, og han sætter ofte de nordiske folk i et særligt rosende lys. Det er derfor ikke sikkert, at hans ord skal tages for pålydende. På den anden side er der som vist ikke kildemæssigt grundlag til at underbygge beskrivelsen af et udsømmeligt levned i de offentlige badstuer, som af og til antydes i faglitteraturen, bl.a. med henvisning til illustrationer af badescener, hvor mænd og kvinder deler badekar. 


\section{Fattige folks badstuegang}

I et bevaret dokument fra 1496 oplistes hvilket inventar, der forefindes i de fattige folks hus og gård i Århus. Efter denne inventarliste tilføjes, at de fattige folk skal have bad hver fjortende dag eller oftere, hvis de har behov for det pga. sygdom. ${ }^{84}$ Ordet »bad" må betegne mere end blot en almindelig afvaskning, som kunne foregå alle vegne, hvor en spand vand var til rådighed. Det fremgår ikke klart, om de fattige skulle bade i byens offentlige badstue, eller om deres hus selv rummede en badstue. At en sådan institution kunne have haft egen badstue fremgår af fundatser til to Skt. Anna hospitaler som Malmøborgeren Claus Denne i 1524 gives tilladelse til at opføre i henholdsvis København og Åhus i Skåne. Om begge hospitaler hedder det, at de skal være så anseelige som noget hospital i Danmark og indeholde badstue og andre bekvemmeligheder til de syge menneskers behov. ${ }^{85}$ Det vides ikke, om disse beslutninger nogensinde er blevet udført, og såfremt fundatsens bestemmelser om en badstue er blevet fulgt, har der efter dokumentets eget udsagn været tale om en ekstraordinært veludstyret institution, så det er langt fra sikkert, at andre hospitaler og fattighuse i landet har haft egne badstuer. Ser man nærmere på inventarlisten for fattighuset i Århus, er der heller ikke noget, der tyder på en egen badstue her. Ud over fem molluger (tolkes som mollinger $=$ vaskefade) og to håndklæder, som sandsynligvis er brugt til vask af hænder og ansigt efter måltidet - og for øvrigt nævnes sammen med bordtøjet - kan intet af inventaret relateres til en badstue. ${ }^{86}$ Det er derfor sandsynligt, at de fattige folk i Århus i slutningen af 1400-tallet badede i byens offentlige badstue.

\section{Sjælebade}

Sjælebade er et fænomen, der ofte forekommer i testamenter fra 14-1500-tallet. Begrebet dækker over, at den testamenterende betaler for, at fattige kan få et badstuebad - ofte med tilhørende bespisning. At skænke midler til de fattige forekommer i danske testamenter igennem hele middelalderen, men i senmiddelalderen specificeres det ofte, at pengene skal anvendes konkret til badstuegang. Også andre kilder end testamenter kan omhandle sjældebade. Fænomenet nævnes første gang $\mathrm{i}$ en dansk kilde i forbindelse med donationen af en badstue til et nystiftet kapel i Ribe Domkirke i 1314. ${ }^{87}$ Også Slesvigbispen donerer badstuegang til fattige i 1452, og i dronning Christines regnskaber er der flere udgiftsposter til sjælebade. ${ }^{88}$

Det er dog hovedsageligt i senmiddelalderlige testamenter, at sjælebadene forekommer. Blandt de trykte testamenter i de anvendte kildesamlinger er der i alt blevet konstateret 18 eksempler på sjælebade udstedt af eller til gavn for 
danske borgere. Ordlyden i testamenterne er som regel meget ens og beskriver, i hvilken by de fattige betænkes med sjælebad, sjælebadenes antal og evt. bespisning i forbindelse med badstuegangen. I nogle testamenter fastslås det, at badstuegangen er en årligt tilbagevendende begivenhed på giverens sjæledag (årsdag for dødsfaldet). Hovedparten af disse testamenter stammer fra anden del af 1400-tallet og begyndelsen af 1500-tallet. Det tidligste testamente er dog fra Stralsundborgeren Timme Swarte, der i 1397 testamenterer de fattige i Trelleborg i Skåne et badstuebad og en tønde øl, »som de drikker for min sjæls skyld «. ${ }^{89}$ Her nævnes eksplicit troen på, at donationen af bad og $ø l$ letter vejen til himmelen for giverens sjæl. Denne tankegang ligger bag donationerne af bade til fattige i middelalderen, hvad enten den godgørende gerning benævnes sjælebad eller simpelthen badstuebad. Fænomenet viser, at man i datiden opfattede badstuegang som noget absolut godt og vederkvægende. At skaffe folk fra samfundets nederste lag adgang til bad betragtedes som en god kristen gerning. Den hyppige forekomst af sjælebade i testamenter viser, at fænomenet var ret udbredt i Danmark i senmiddelalderen.

Af næsten samtlige testamenter, hvor sjælebade nævnes, fremgår det, at der betales for øl og mad i forbindelse med badstuebesøget. Det har altså været almindeligt at spise og drikke i badstuerne. Dette står i modsætning til, hvad Olaus Magnus hævder i »Historia om de nordiska folken«. Som nævnt er værket ikke fri for en tendentiøs undertone, og Olaus Magnus anfører, at denne usædelige - muligvis nordtyske - skik ikke forekommer i de nordiske badstuer. ${ }^{90}$ De danske testamenter fra middelalderen bekræfter dog entydigt, at spisning forekom i badstuerne. De måltider, der blev serveret i forbindelse med peblingenes og de fattiges badstuegang, bestod af flæsk, sild, brød, smør og øl.

Ved reformationen forsvinder sjælebadene fra testamenterne. Den sidste badstuegang til fattige findes ifølge Troels-Lund i testamentet for kannik Jens Jørgensen i Roskilde fra $1558 .{ }^{91}$ Der synes at være flere forskellige grunde til sjælebadenes ophør: For det første var sjælebadene ikke forenelige med den protestantiske trospraksis, idet den katolske skik at fejre den afdødes sjæledag forsvandt ved reformationen, og dermed fjernedes grundlaget for de årlige badstuegange, der som testamentariske donationer forvaltedes af kirkelige institutioner. For det andet kom badstuerne i 1500-tallet i miskredit som smittekilder for syfilis, hvorfor det ikke længere var passende at give fattige folk adgang til disse institutioner. For det tredje medførte det faktum, at den katolske kirke ikke længere tog omsorg for de fattige, en tilbøjelighed til i testamenterne først og fremmest at betænke de trængende, der stod giveren nærmest - f.eks. tjenestefolk o.l. ${ }^{92}$ Sjælebadenes ophør har formentlig været en medvirkende faktor i badstuernes tilbagegang. 


\section{Badstuernes tilbagegang}

I flere historiske oversigtsværker nævnes det, at syfilisen i begyndelsen af 1500-tallet førte til lukning af de offentlige badstuer. ${ }^{93}$ I disse værker henføres de offentlige badstuer til at være et rent middelalderfænomen, der ved reformationen enten er forsvundet eller under afvikling. Troels-Lund antyder dog, at lukningen ikke nødvendigvis var altomfattende eller permanent. ${ }^{94}$ Det skal her påpeges, at det offentlige badstuevæsen i Danmark nok var i tilbagegang omkring reformationen, og sandsynligvis er badstuerne forsvundet for stedse i de mindre købstæder på dette tidspunkt. Men i de største købstæder som København og Malmö eksisterede offentlige badstuer helt frem til omkring år 1700. Det nævnes i flere værker specifikt, at de offentlige badstuer i København lukkes i året 1509, ${ }^{95}$ men da der ingen steder er henvisning til de historiske kilder, som ligger bag denne oplysning, må dette indtil videre betragtes som en påstand ${ }^{96}$ En eventuel lukning af badstuerne i København i 1509 har i hvert fald ikke været permanent, idet der i løbet af 1600-tallet kendes flere offentlige badstuer, som drives af navngivne badstuemænd. ${ }^{97}$ Det samme er tilfældet i Malmø, hvor badstuevæsnet kan følges i 15-1600-tallet. Fra og med år 1634 har Malmø dog kun én offentlig badstue..$^{9}$ Den sidste badstue i København lukker i $1712,{ }^{99}$ og i Malmø lukkes den sidste offentlige badstue, da den sidste badstuemand i Skåne dør i 1709.100

Der kan opstilles flere forskellige årsager til, at badstuevæsnet fra at være et levende og udbredt fænomen i købstæderne i løbet af 1500-tallet efterhånden langsomt sygner hen for til sidst endegyldigt at forsvinde fra bybilledet. De nedenfor nævnte årsager har formentlig i forskellig grad bevirket badstuernes afvikling.

\section{Syfilis}

Fra 1490'erne hærgede en hidtil ukendt sygdom i Europa, nemlig syfilis, der i datiden gik under betegnelserne franzoser eller pokker. I Roskildeårbogen fra anden halvdel af 1500-tallet oplyses det, at sygdommen første gang kom til det kristne Europa i $1493,{ }^{101}$ mens andre kilder angiver andre årstal. ${ }^{102}$ Disse specifikke årstal kan man ikke tillægge speciel vægt, og der hersker en igangværende videnskabelig diskussion om, hvorvidt syfilis fandtes i Europa, før Columbus vendte tilbage fra Sydamerika, eller om sygdommen kom til Europa herfra. ${ }^{103}$ Faktum er dog, at man fra omkring år 1500 også i Danmark stod over for epidemier af en sygdom, man hidtil ikke havde kendt, og at man mente, at sygdommen blev spredt via bl.a. badstuerne.

Datidens sammenkædning af badstuevæsnet og udbredelsen af syfilis fremgår af to religiøse tekster fra reformationstiden, nemlig Peder Palladius' bog 
»Om Hosedjevelen« fra 1528 og Povl Helgesens bog »Om kranke etc. Mennesker« fra 1556. ${ }^{104}$ I reformationstidens kirkekampe var Peder Palladius fortaler for den lutherske lære, mens Povl Helgesen var reformkatolsk teolog, der ønskede at rette op på den katolske kirkes fejl, men samtidig også kritiserede den protestantiske lære. ${ }^{105}$

I sin lærebog om håndtering af syge mennesker nævner Povl Helgesen faren for, at sygdomme spredes via badstuerne og gør opmærksom på faren ved, at alle bader i samme badstue. Den skade, det forårsager, er allerede velkendt, siger Helgesen. ${ }^{106}$ Det er imidlertid forkert at gøre Povl Helgesen til fortaler for badstuernes lukning, hvilket flere historikere har gjort. ${ }^{107}$ Tværtimod taler han for oprettelsen af flere badstuer, så syge og raske personer ikke anvender samme badstue. ${ }^{108}$

Peder Palladius (1502-60) var en af reformationstidens store teologer, og han var bl.a. biskop over Sjællands Stift og professor i teologi ved universitetet i København. ${ }^{109}$ Fra hans hånd er bevaret ca. 80 værker i form af henholdsvis egne tekster og oversættelser. Badstueproblematikken nævnes i bogen »Om Hosedjæevelen", der er et stykke opbyggelseslitteratur med et moraliserende sigte. Bogen er en oversættelse fra tysk med Palladuis' egne tilføjelser og omhandler de skikkelser, som djæevelen kan antage - bl.a. personificeret i de udenlandske landsknægte, der vandrer omkring i København i flagrende hoser. Bogen er altså generelt et udfald mod udskejelser, fråds og forfængelighed og sammenkæder syfilis og badstuer med et generelt moralsk forfald i tiden. ${ }^{110}$ Palladius mener, at pokkeren er kommet fra Frankrig sammen med den almindelige løsagtighed $\mathrm{i} » k l æ d e r$ og sæder«. Han meddeler, at syfilisen var årsag til, at badstuer i hans barndom lukkede alle vegne, bl.a. i hans egen fødeby Ribe, hvor badstuen aldrig genåbnede. Man havde i samtiden kun en begyndende forståelse for, at syfilis var en seksuelt overført sygdom, og sammenkædningen mellem syfilis og badstuevæsnet er derfor ikke nødvendigvis udtryk for, at Palladius mente, at der her foregik seksuelle udskejelser. Den nye sygdom betragtedes i lige så høj grad som en konsekvens af generel moralsk degenerering som af seksuelle handlinger. Palladius' skrift kan ikke tolkes som et direkte angreb på badstuerne, men i kraft af den moraliserende sammenhæng, citatet indgår i, må man alligevel formode, at Palladius var tilfreds med, at der var sat en stopper for badstueuvæsnet.

De midlertidige lukninger af badstuerne pga. epidemier, som antydes i kilderne, kan have medvirket til, at kunderne har undgået badstuerne, hvis eller når de blev genåbnet. Således kan der have været en vekselvirkning mellem, at badstuer faktisk blev lukket i perioder og et svigtende kundegrundlag, som tilsammen førte til badstuernes endelige nedgang. 


\section{Sjælebade forsvinder}

Én kundegruppe, der i hvert fald med sikkerhed vides at forsvinde fra badstuerne, er de fattige, der i katolsk tid modtog sjælebade. Som nævnt sker der en kraftig tilbagegang i udstedelsen af sjelebade omkring reformationen, og snart er fænomenet helt forsvundet. I en bog, der er trykt i 1533 som indlæg i kampen mellem katolicisme og protestantisme, nævnes sjælebadenes forsvinden eksplicit. ${ }^{111}$ Bogen er en satire på vers over den papistiske messe, i hvilken forskellige gejstlige beklager sig over de nye tider, hvor skærsilden med ét er slukket »og tog med sig den store skare, som jeg nu for Eder vil åbenbare: psalter, vigilier og sjælebad, derfor er jeg ikke meget glad ${ }^{112}{ }^{12}$ Ikke bare kirken lider økonomisk tab ved sjælebadenes forsvinden, men også badstuerne mister formentlig en væsentlig del af deres indkomst.

\section{Opkomst/vækst af private badstuer}

Muligvis kan en vækst af badstuer i private hjem i tiden umiddelbart efter middelalderen have været medvirkende til, at offentlige badstuer i eftermiddelalderlig tid ikke længere var lukrative forretninger. I anden halvdel af 1500-tallet nævner de skriftlige kilder flere eksempler på private badstuer i samfundets øverste lag. Således indrettes badstuer både ved en præstebolig ved Vor Frue Kirke i København og i flere af Universitetets professorresidenser. ${ }^{113}$ Ligeledes er der efterretninger om, at en privatmand i Ribe midt i 1500-tallet bygger en badstue, ${ }^{114}$ og i 1575 opfører tømrere en badstue i Puggård, rektorboligen ved Ribe katedralskole. ${ }^{115}$ I 1610 skøder borgeren Knud Gyldenstjerne Axelsen til kongen en gård, i hvis have der står en badstue. ${ }^{116}$ Hvorvidt antallet af omtalte private badstuer skyldes en stigende mængde bevarede kilder, eller om det er udtryk for en reel stigning af private badstuer, er dog uklart.

\section{Ændrede moralske normer og badevaner}

Samtidig med at private badstuer muligvis bliver mere almindelige i samfundets øverste lag, er der også en modsatrettet tendens i datiden, som synes at medføre ændrede holdninger til badning, hvilket resulterer i et tilbageskridt i den personlige hygiejne på overgangen fra middelalder til nyere tid.

Flere historikere ser således en sammenhæng mellem reformationen og lukningen af badstuerne. Bl.a. skriver Duerr, at hvad pest og syfilis ikke havde fået færdiggjort, lykkedes for reformationen - nemlig lukning af badstuerne. ${ }^{117}$ Det vil her føre for vidt at gå ind på diskussionen om, hvorvidt der faktisk skete en ændring i holdningen til eksempelvis offentlig nøgenhed ved overgangen fra katolsk til protestantisk tid, det skal blot nævnes, at emnet bl.a. behandles af Duerr og Seeberg. ${ }^{118}$ 
Troels-Lund anfører som den egentlige årsag til badstuernes endelige nedgang, at brugen af linned i form af undertøj og lagner førte til ændrede badevaner hos befolkningen. Kroppen var pga. linned i mindre grad end tidligere udsat for at blive beskidt, og man sørgede for at holde kroppens omgivelser (lagner m.v.) rene snarere end at vaske kroppen. ${ }^{119}$

At der virkelig skete en nedgang $i$ den personlige hygiejne $\mathrm{i}$ århundrederne efter middelalderen, kan man læse ud af skriftlige kilder fra tiden. Bl.a. klager den sidste badstuemand i Malmø omkring år 1700 over manglende indtægt, fordi svenskerne ikke ynder at bade. ${ }^{120}$ Senere i 1700 -tallet parafraserer genealogen Terkel Klevenfeldt over et nu forsvundet regnskab fra Christoffer af Bayerns hof holdning i $1447 .{ }^{121}$ Klevenfeldt henviser til, at kongen havde brugt ikke færre end 8 mark på en privat badstuegang, mens småsvendene tilsammen måtte nøjes med 8 skilling. Men endnu mere end prisen undrer Klevenfeldt sig over, at kongen overhovedet brød sig om at gå i bad: "Sligt synis vel unødvændige Ting [...] maaske var det en bayersk Skick, maaske lærer mand deraf, at de nordiske Folck vare fordum mere nette og reenlige en(d) de for Tiden nu ere«. ${ }^{122}$ Det ser altså ud til, at der virkelig skete en forværring af folkerenligheden efter middelalderen. Først med voksende kendskab til bakterier og hygiejne samt med fremkomsten af offentlige badeanstalter i byerne i løbet af 1800-tallet ændrer dette billede sig igen.

\section{Fremtidig badstueforskning}

I sit skrift fra 1556 nævner Palladius, at badstuen i Ribe lukkede i hans barndom og aldrig siden åbnedes. Dog, nævner han, bærer grundstykket stadig navn efter badstuen, lige som gaden kaldes Badstuegade. Som det ovenstående har vist, beretter skriftlige kilder og stednavne om et badstueliv, der var betydningsfuldt for middelalderens bysamfund. Endnu er den arkæologiske viden om disse institutioner begrænset både i Danmark og de øvrige lande omkring Østersøen, men med en større forstålse for badstuernes placering både i det fysiske og mentale bybillede i middelalderen samt viden om badstuernes konkrete brug, er der mulighed for, at man ved fremtidige arkæologiske udgravninger kan frembringe fysiske levn af de forsvundne badstuer.

\section{NOTER}

1. En samlet oversigt over skriftlige og arkæologiske kilder kan findes i mit speciale "Badstuer i det middelalderlige Danmark. Konstruktion, udbredelse og brug«, som i foråret 2008 er under udgivelse.

2. Tuchen 2003, s. 22-23. 
3. Bonneville 1998, s. 174.

4. Nielsen 1877, Del 1, s. 300; Rørdam 1859-63, tillæg s. 133.

5. Sundt 1975, s. 312.

6. Sveinbjarnardóttir 2005, s. 214.

7. Kulturhistorisk leksikon for nordisk middelalder I, spalte 296-298.

8. Sundt 1975, s. 311-317.

9. Hinz 1953.

10. Roesdahl 1998, s. 40-41.

11. Roesdahl 1998, s. 40-41.

12. Kulturhistorisk leksikon for nordisk middelalder I, spalte 296-298.

13. Danstrup \& Koch 1976, s. 304; Islandske sagaer bd. 5, s. 44-45.

14. Magnusson 1976, s. 100.

15. Denne tolkning foreslås i Kaldal Mikkelsen 2003, s. 84; i den oprindelige publikation tolkes grubehuset som bolig. Andersen, Crabb og Madsen 1971, s. 46-48.

16. Matthiessen 1915, s. 69.

17. Saxo, s. 220-221.

18. Saxo, s. 226-227.

19. Saxo, s. 428-429.

20. Testamenter fra Danmarks Middelalder indtil 1450, s. 10; Diplomatarium Danicum, 2. rk. 1. bd., nr. 233.

21. Testamenter fra Danmarks Middelalder indtil 1450, s. 18; Diplomatarium Danicum, 2. rk. 2. bd., nr. 150

22. Diplomatarium Flensborgense II, s. 887.

23. Blomqvist 1951, s. 362-63; Andrén 1984, s. 20 og 120.

24. Diplomatarium Danicum, 2. rk. 7. bd., nr. 173.

25. Købstæder, i hvilke mindst en middelalderlig badstue må have eksisteret, er: Assens, Flensburg, Haderslev, Halmstad, Helsingborg, Horsens, Husum, København, Køge, Landskrona, Lund, Malmö, Nakskov, Nyborg, Næstved, Odense, Ribe, Roskilde, Slagelse, Slesvig, Store Heddinge, Svendborg, Tommarp, Trelleborg, Ystad og Århus. Stednavnemateriale sandsynliggør, at der også har været middelalderlige badstuer i Nykøbing Falster, Randers, Viborg og Vordingborg.

26. Vommebadstuen (Kbh.), badstuen ved Nørreport (Ribe), badstuen i Grønnegade (Ribe), Kuntzes badstue (Malmö) og Mogens Tuesens badstue (Næstved).

27. Ud over de ovenfor nævnte eksempler ejede også Skt. Peders Kirke i Næstved (1484), Vor Frue Kirke i Slagelse (1469) og Vor Frue Kirke i Flensborg badstuer (1537). Danske Magazin 1. rk. 1. bd., s. 269-272, Rep. 2. rk. 2. bd. s. 136; Diplomatarium Flensborgense II, nr. 398.

28. Skt. Agnete Kloster i Roskilde, Skt. Knud Kloster i Odense og Helligåndsklostret i København og Skt. Peders Kloster i Tommarp (Diplomatarium Danicum, 3. rk. 2. bd., nr. 46).

29. Martin 1906, s. 64-66; Tuchen 2003, s. 24.

30. Carlsson 1947, s. 116-118.

31. Kulturhistorisk leksikon for nordisk middelalder VII, spalte 195.

32. Troels-Lund bd. 1, s. 494.

33. Saxo, s. 226-227.

34. Karker 1995, s. 91.

35. Danske Helgeners Levned 1893-94, s. 387. 
36. Repertorium diplomaticum 2. rk. 1. bd., s. 65.

37. Kjøbenhavns diplomatarium IV, s. 388.

38. Nielsen 1877, 1. bd., s. 300.

39. Kirkehistoriske Samlinger 2. rk. 5. bd. (Ny Kirkehistoriske Samlinger), s. 73.

40. Tuchen 2003, s. 21-22.

41. Martin 1906, s. 144-171.

42. Tuchen 2003, s. 35 .

43. Tuchen 2003, s. 27-28; Cramer 1985, s. 35.

44. Troels-Lund bd. 1, s. 550-551; Roland \& Høst-Madsen 2000, s. 17.

45. Duerr 1994, s. 43-46.

46. Martin 1906, s. 144-171; Tuchen 2003, s. 29-35.

47. Diplomatarium Danicum, 3. rk. 3. bd., nr. 285 (1350); 3. rk. 3. bd. nr. 590 (1352); Pedersen bd. V, s. 463: „hand hagde icke mere en[d] en badelagen paa sigh wnder sin kiortell“: Martin 1906, s. 104-5.

48. Henrik Harpestrengs danske Lægebog, s. 4.

49. Bergmark 1985, s. 83.

50. Martin 1906, s. 9.

51. Martin 1906, s. 8.

52. Anderson 1972, s. 132.

53. Bennike \& Brade 1999, s. 35.

54. Møller-Christensen 1944, s. 74-75.

55. Hauberg 1982, s. 10.

56. Nedenstående er baseret på min egen oversættelse til nudansk af de håndskrifter, som findes på tryk i Henrik Harpestrengs danske Lægebog (red. Molbech), s. 55-56, 72; Hauberg 1982, s. 110-11; Karker 1993, s. 91-93 med brug af Ordbog til det celdre danske Sprog samt de ordforklaringer, som de nævnte værker indeholder.

57. Amman \& Sachs 1973, s. 61.

58. Martin 1906, s. 74

59. Danske middelalderlige regnskaber 3. rk. 1. bd., s. 121, $355 \& 366$.

60. Dronning Christines Hofholdningsregnskaber, s. 312 \& 363.

61. Møller-Christensen 1944, s. 88.

62. Flensborg bys historie 1953, s. 127.

63. Diplomatarium Flensborgense II, nr. 361.

64. I Tyskland oprettes lav af badstuemænd i bl.a. Lüneburg 1361 (Lübecker Kolloquium IV, s. 243), Würzburg 1373 og Hamburg 1375 (Tuchen 2003, s. 25).

65. Agri 1930, s. 14-15.

66. Bruun 1887-1901, bd. II, s. 377.

67. Om københavnske badstuemænd i 1600-tallet, se Lindberg 1996, bd. II, s. 229-230.

68. Lübecker Kolloquium Iv, s. 243; Tuchen 2003, s. 25.

69. Brugen af kohorn fremgår af en illustration til "Historia om de nordiska folken«. Magnus 3. del, s. 164.

70. Hauberg 1982, s. 102-110.

71. Møller-Christensen 1944, s. 107; Dr. Chr. Hofh., s. 312 \& 363.

72. Møller-Christensen 1944, s. 107.

73. Magnus, 3. del, s. 165.

74. Diplomatarium Danicum, 2. rk. 2. bd, nr. 150.

75. Diplomatarium Danicum, 3. rk. 3. bd, nr. 262. 
76. Danmarks gamle ordsprog, bd. VII:2, s. 242.

77. Danske Magazin, 4. rk. 1. bd., s. 66 \& 89.

78. Dronning Christines Hofholdningsregnskaber, s. 88.

79. Danske middelalderlige regnskaber, 1. rk. 1. bd., s. 21 \& 28-29.

80. Danske Magazin, 3. rk. 6. bd, s. 7, 13-14 \& 25. Ordet drikkepenge forekommer også i regnskaberne i forbindelse med badstuegang: »till Dricke penge og bastuegang vj s«, 3. rk. 6. bd., s. 13.

81. Repertorium diplomaticum, 2. rk. 1. bd., s. 65.

82. Martin, 1906, s. 86-90.

83. Magnus, 3. del, s. 164-65.

84. Repertorium diplomaticum. 2. rk. 4. bd, s. 618-19.

85. Rørdam 1859-1863, s. $350 \& 352$ + Tillæg nr. 120: » eth merkeligt hospitall, szom noget kandt findis vti Danmarck, vpmwret aff grwndenn och indenn bygning met bastue och anden qwemhedt, som siwge mendische sunderligenn behoff haffue«.

86. Repertorium diplomaticum, 2. rk. 4. bd, s. 618.

87. Diplomatarium Danicum, 2. rk. 7. bd., nr. 232.

88. Repertorium diplomaticum, 2. rk. 1. bd., s. 65; Dronning Christines Hofholdningsregnskaber, s. 85, 98, 373, 374 .

89. Diplomatarium Danicum, 4. rk. 6. bd., nr. 416.

90. Magnus, 3. del, s. 165.

91. Troels-Lund, bd. 7, s. 230; Monumenta historiæ Danicæ, 2. rk. 2. bd., s. 43.

92. Troels-Lund, bd. 7, s. 227-231.

93. Troels-Lund, bd. 1, s. 500; Bruun 1887, del 1, s. 216; Wittendorff 1989, s. 338; Schiørring 1984, s. 20; Roskilde bys historie, s. 296; Bonneville 1998, s. 39, Møller 1998, s. 161.

94. Troels-Lund, bd. 1, s. 500.

95. Agri 1930, s. 13; Københavns hvornår skete det 1979, s. 2; Lindberg 1996, bd. 1, s. 92 \& 111.

96. Heller ikke i forbindelse med nærværende arbejde har det været muligt at finde den pågældende skriftlige kilde hverken i de anvendte kildesamlinger eller ved personlig kommunikation med Københavns Bymuseum og Københavns Stadsarkiv.

97. Lindberg 1996, bd. 2, s. 227, $229 \& 285$.

98. Agri 1930, s. 13-51.

99. Lindberg 1996, bd. 2, s. 229.

100. Agri 1930, s. 50-51.

101. Monumenta historiæ Danicx, I, 1873, s. 318.

102. Møller-Christensen 1944, s. 196.

103. Seeberg 1989, s. 45-46; Bennike \& Brade 1999, s. 65-68.

104. Den fulde titel er "Huore krancke, mijslige, saare, arme oc fattige menniskir schule tracteris oc besørgis, een kort vnderwijsnng aff broder Paulo Heilie«.

105. Dansk biografisk leksikon, 6. bd., s. 210-12.

106. Helgesen, 3. bd., s. 12.

107. Sådan tolkes Povl Helgesens skrift af Lis Jacobsen i Peder Palladius' danske Skrifter, bd. 4, s. 76, samt i Lindberg 1996, bd. 1, s. 111-112 og i Møller-Christensen 1941, s. 14.

108. Helgesen 3. bd., s. 12.

109. Dansk biografisk leksikon, 6. bd., s. 210-212.

110. Palladius, 4. bd., s. 48-49. 
111. Danske Magazin, 1. rk. 2. bd., s. 53-64, 84-95 \& 103-107.

112. Danske Magazin, 1. rk. 2. bd., s. 106. Her gengivet med moderne retstavning.

113. Rørdam 1868-69, s. 681, 71, 72, 74.

114. Kinch 1876-77, s. 205.

115. Peder Hegelunds almanakoptegnelser, I, s. 103 (9. marts 1575).

116. Kjøbenhavns diplomatarium, II, nr. 668.

117. Duerr 1994, s. 53.

118. Duerr 1994; Seeberg 1989.

119. Troels-Lund, bd. 1, s. 500.

120. Agri 1930, s. 47-48.

121. Danske middelalderlige regnskaber, 1. rk. 1. bd., s. 24-31.

122. Danske middelalderlige regnskaber, 1. rk. 1. bd., s. 28-29.

\section{LITTERATUR}

Agri, Janne 1930: Bland yrkesmän i gamla dagar. Vardagsbild från 1600-tallets Malmö. Lund. Amman, Jost \& Hans Sachs 1973: Book of Trades, The (Ständebuch). New York: Dover.

Andersen, H. Hellmuth, P.J. Crabb \& H.J. Madsen 1971: Århus Søndervold. En byarkaologisk undersøgelse. Højbjerg.

Anderson, Iwar 1972: Vadstena gård och kloster. Stockholm.

Andrén, Anders 1984: Lund. Tomtindelning, ägostruktur, sockenbildning. Medeltidsstaden; 56. Lund.

Bennike, Pia \& Anna-Elisabeth Brade 1999: Middelalderens sygdomme og behandlingsformer $i$ Danmark. København.

Bergmark, Matts 1985: Bad och bot. Om vatten som läkemedel och njutingsmedel. Stockholm.

Blomqvist, Ragnar 1951: Lunds Historia 1 Medeltiden. Lund.

Bonneville, François de 1998: The Book of the Bath. London.

Bruun, Carl 1887-1901: Kjøbenhavn, 1887-1901. København.

Carlsson, Lizzie 1947: Om bad och badstugor i äldre tid, Rig Kulturhistorisk tidsskrift, 1947:3, s. $113-141$.

Cramer, Johannes 1985: Badhäuser - Ein städtischer Bautyp. Hausbau im Mittelalter II (Jahrbuch für Hausforschung; Sonderband).

Danmarks gamle ordsprog 1977-88: I. Kjær og J. Kousgård Sørensen (red.). København.

Dansk biografisk leksikon 1979-83: Sv. Cedergreen Bech (red.). København.

Danske Helgeners Levned 1893-94: H. Olrik (red.). København.

Danske Magazin 1745-. København.

Danske middelalderlige regnskaber 1944-53: Georg Galster \& C.A. Christensen (red.). København.

Danstrup, John \& Hal Koch 1976: Normannertiden 600-1060. Danmarks Historie, bd. 2. København.

Diplomatarium Danicum 1938-. København.

Diplomatarium Flensborgense. Aktstykker til Staden Flensborgs Historie indtil Aaret 1559, 1865-73: H.C.P. Sejdelin (red.). København.

Dronning Christines Hofholdningsregnskaber 1904: William Christensen (red.). København.

Duerr, Hans Peter 1994: Nakenhet och skam. Myten om civilisationsprocessen, bd. 1. Stockholm.

Flensborg bys historie bd. 1 1953: H. Hjelholt m.fl. (red.). København. 
Hauberg, Poul 1982: Lagebøger med tilknytning til Henrik Harpestrang. København.

Helgesen, Povl 1932-48: Skrifter af Paulus Helie. København.

Henrik Harpestrengs danske Lagebog fra det trettende Aarhundrede 1826: Christian Molbech (red.). København.

Hinz, Hermann 1953: Eine germanische Sauna aus Rantrum. Die Heimat 1953:60, s. 20-22.

Islandske sagaer. Eyrbyggja Saga og Vatnsdala Saga 1970: P. Rohde (red.). København.

Kaldal Mikkelsen, Dorthe 2003: Boligfunktioner i vikingetidens gårde. I: Else Roesdahl (red.): Bolig og familie i Danmarks middelalder. Højbjerg.

Karker, Allan 1993: Dansk i tusind år. København.

Kinch, J. 1876-77: Af Ribe Bys Tingbeger fra første Halvdel af det 17de Århundrede, Samlinger til Jydsk Historie og Topografi, 1. rk. 6. bd.

Kirkehistoriske Samlinger 1849-. København.

Kjøbenhavns diplomatarium 1872-87: (red. O. Nielsen). København.

Kulturhistorisk leksikon for nordisk middelalder: fra vikingetid til reformationstid 1956-78: Allan Karker m.fl. (red.). København m.fl.

Københavns hvornår skete det 1979: Lisbeth Andersen \& Steffen Lindvald (red.). København.

Lindberg, Kirsten 1996: Sirenernes stad. København. By- og bygningshistorie før 1728 I-III. Ebeltoft.

Lübecker Kolloquium zur Stadtarchäologie im Hanseraum IV. Die Infrastuktur 2004: Dunckel m.fl. (red.). Lübeck.

Magnus, Olaus 1976: Historia om de nordiska folken: John Granlund (red.). Stockholm.

Magnusson, Thor 1976: Ett vikingatida gårdsanlägg i Hvitarholt, Island, Iskos 1976:1, s. 99-103.

Martin, Alfred 1906: Deutsches Badewesen in Vergangenen Tagen. Jena.

Matthiessen, Hugo 1915: Borgemester Mogens Tuessøns Badstue i Næstved. Et lille bidrag til Næstved Bys Historie. Aarbog for Historisk Samfund for Prestø Amt 1915, s. 69-88.

Monumenta historice Danica 1873-1887: H.F. Rørdam (red.). København.

Møller, Jan 1998: Borger i middelalderens København. København.

Møller-Christensen, Vilh. 1944: Middelalderens lagekunst i Danmark. København.

Møller-Christensen, Vilh. 1941: Om kirurgisk behandling af den galliske syge i Danmark før 1550. Århus.

Nielsen, Oluf 1877: Kjøbenhavns Historie og Beskrivelse. Bind 1. København.

Palladius, Peder 1911-26: Peder Palladius' danske Skrifter: Lis Jacobsen (red.). København.

Peder Hegelunds almanakoptegnelser 1565-1613, bd. I, 1976: Bue Kaae (red.). Ribe.

Pedersen, Christiern 1850-56: Danske Skrifter. København.

Repertorium diplomaticum regni Danici medicevalis: Fortegnelse over Danmarks Breve fra Middelalderen 1894-1939: Kr. Erslev (red.). København.

Roesdahl, Else 1998: Vikingernes verden. København.

Roland, Thomas \& Lene Høst-Madsen 2005: Borgmesterens badstue, Skalk 2000:5, s. 13-17.

Roskilde bys historie - tiden indtil 1536, 1992: Frank A. Birkebæk m.fl (red.). Roskilde.

Rørdam, H.F. 1859-63: Kjøbenhavns Kirker og Klostre i Middelalderen. København.

Rørdam. H.F. 1868-69: Kjøbenhavns Universitets Historie fra 1537 til 1621. København.

Saxo Grammaticus 2005: Gesta Danorum, Danmarkshistorien. Karsten Friis-Jensen (red.), dansk oversættelse af Peter Zeeberg, bind 2. København. 
Schiørring, Ole 1984: Midtbyens udvikling 900-1600. I: Ole Østergaard \& Claus Navntoft (red.): Den indre by Århus, registrering af bevaringsvardige bygninger og miljøer. Århus, s. 11-21.

Seeberg, Peter 1989: Syfilis og badeanstalter, Den jyske historiker 1989:48, s. 34-50.

Sundt, Eilert 1975: Om renligheds-stellet $i$ Norge. Verker $i$ Utvalg; bd. 9. Oslo.

Sveinbjarnardóttir, Gudrun 2005: The use of geothermal resources at Reykholt in Borgarfjördur in the medieval period. Viking and Norse in the North Atlantic Andras Mortensen \& Símun V. Arge (red.), s. 208-216.

Testamenter fra Danmarks Middelalder indtil 1450, 1901: Kr. Erslev (red.). København.

Troels-Lund, Troels 1968: Dagligt liv i Norden i det sekstende århundrede (6. udg.). København.

Tuchen, Birgit 2003: Öffentliche Badhäuser in Deutschland und der Schweiz im Mittelalter und der Frühen Neuzeit. Petersberg.

Wittendorff, Alex 1989: På Guds og herskabs nåde 1500-1600. Gyldendal og Politikens Danmarkshistorie, bd. 7. København. 


\section{Bath-houses in medieval Denmark}

\section{- a cultural history}

The subject of this article is bath-houses in medieval Denmark. The text is based on all available written sources from Denmark, but in order to obtain a fuller perspective on some aspects of the history of bath-houses it has also been necessary to use German sources as a supplement.

Based on the scant historical records dealing with the course of actual bathing activity, it is argued that the most common bath was the sweat bath (similar to a modern sauna) rather than tub baths. A stove covered with granite boulders was heated and the bathers would produce sweat using either the direct heat of the stove or from steam produced by pouring cold water onto the hot stones. Sweating was further stimulated by beating the body with bundles of birch twigs and the bath culminated with rinsing in cold water (figs. 2-4). It is argued that, similar to the situation in both Germany and Sweden, bath-house staff would offer haircuts, bleeding and the treatment of wounds in addition to an actual bath (figs. 5-6). Referring to specific medieval illustrations, some argue that men and women bathed together in the public bath-houses, leading to sexual excesses. However, the relevant illustrations often depict brothels and not public baths (fig. 1).

It is evident from historical records that members of all social classes frequented the public bath-houses - even royalty.
From the early 14 th century onwards we have historical evidence of so-called soul baths i.e. sums of money bequeathed by wealthy people to the poor to enable the latter to take a bath, often accompanied by a meal. Such bequests were common in the late 15 th century but disappeared abruptly with the Reformation. According to medieval records, the use of bathhouses was also considered important in order to maintain health.

The earliest indications in historical records of the existence of bath-houses in Denmark are found in Saxo's Chronicles from the end of 12th century. From the 1260s onward specific bath-houses in towns appear in the historical records. Judging from the number of bath-houses mentioned in Danish towns it is argued that public bath-houses were a common feature in the urban landscape of medieval Denmark.

The number of public bath-houses in towns declined at the beginning of the 16th century and even though a few existed in the major cities up until the 18th century the popularity of these institutions declined. The reasons for this are epidemics of syphilis occurring from the 1490s onward, the phasing out of soul baths and possibly a change in attitudes towards nudity and personal hygiene that resulted in a decline in general cleanliness in postmedieval times. 